\title{
Maitotoxin-4, a Novel MTX Analog Produced by Gambierdiscus excentricus
}

\author{
Francesco Pisapia 1,* (D), Manoëlla Sibat ${ }^{1}$ (D), Christine Herrenknecht ${ }^{2}$ (D), Korian Lhaute ${ }^{1}$, \\ Greta Gaiani $^{3}$, Pierre-Jean Ferron ${ }^{4}$ (D), Valérie Fessard ${ }^{4}$, Santiago Fraga ${ }^{5}$ (D), Silvia M. Nascimento ${ }^{6}$,
} R. Wayne Litaker ${ }^{7}$, William C. Holland ${ }^{7}$, Catherine Roullier ${ }^{2}$ (D) and Philipp Hess ${ }^{1}$

1 Ifremer, Phycotoxins Laboratory, rue de l'Ile d'Yeu, BP 21105, F-44311 Nantes, France; manoella.sibat@ifremer.fr (M.S.); korian.lhaute@ifremer.fr (K.L.); philipp.hess@ifremer.fr (P.H.)

2 Mer Molécules Santé (MMS) Laboratory EA2160, University of Nantes, LUNAM, Pharmacy Faculty, 9 rue Bias, F-44035 Nantes, France; christine.herrenknecht@univ-nantes.fr (C.H.); catherine.roullier@univ-nantes.fr (C.R.)

3 Department of Life Science, University of Trieste, Via Giorgieri 5, 34127 Trieste, Italy; gaiani.greta@gmail.com

4 Toxicology of Contaminants Unit, ANSES Laboratory-French Agency for Food, Environmental and Occupational Health and Safety, Fougères, 10 B rue Claude Bourgelat, 35133 Javené, France;

ferron.pj@gmail.com (P.-J.F.); valerie.fessard@anses.fr (V.F.)

5 Instituto Español de Oceanografía (IEO), Centro Oceanográfico de Vigo, Subida a Radio Faro 50, 36390 Vigo, Spain; santi.fraga@vi.ieo.es

6 Laboratório de Microalgas Marinhas, Departamento de Ecologia e Recursos Marinhos, Universidade Federal do Estado do Rio de Janeiro (UNIRIO), Rio de Janeiro 22290-240, Brazil; silvia.nascimento@unirio.br

7 National Oceanic and Atmospheric Administration, National Ocean Service, National Centers for Coastal Ocean Science, Center for Coastal Fisheries and Habitat Research (CCFHR), 101 Pivers Island Road, Beaufort, NC 28516, USA; wayne.litaker@noaa.gov (R.W.L.); chris.holland@noaa.gov (W.C.H.)

* Correspondence: francesco.pisapia@ifremer.fr; Tel.: +33-649-738-646

Received: 13 June 2017; Accepted: 5 July 2017; Published: 11 July 2017

\begin{abstract}
Maitotoxins (MTXs) are among the most potent toxins known. These toxins are produced by epi-benthic dinoflagellates of the genera Gambierdiscus and Fukuyoa and may play a role in causing the symptoms associated with Ciguatera Fish Poisoning. A recent survey revealed that, of the species tested, the newly described species from the Canary Islands, G. excentricus, is one of the most maitotoxic. The goal of the present study was to characterize MTX-related compounds produced by this species. Initially, lysates of cells from two Canary Island G. excentricus strains VGO791 and VGO792 were partially purified by (i) liquid-liquid partitioning between dichloromethane and aqueous methanol followed by (ii) size-exclusion chromatography. Fractions from chromatographic separation were screened for MTX toxicity using both the neuroblastoma neuro-2a (N2a) cytotoxicity and $\mathrm{Ca}^{2+}$ flux functional assays. Fractions containing MTX activity were analyzed using liquid chromatography coupled to high-resolution mass spectrometry (LC-HRMS) to pinpoint potential MTX analogs. Subsequent non-targeted HRMS analysis permitted the identification of a novel MTX analog, maitotoxin-4 (MTX4, accurate mono-isotopic mass of $3292.4860 \mathrm{Da}$, as free acid form) in the most toxic fractions. HRMS/MS spectra of MTX4 as well as of MTX are presented. In addition, crude methanolic extracts of five other strains of G. excentricus and 37 other strains representing one Fukuyoa species and ten species, one ribotype and one undetermined strain/species of Gambierdiscus were screened for the presence of MTXs using low resolution tandem mass spectrometry (LRMS/MS). This targeted analysis indicated the original maitotoxin (MTX) was only present in one strain (G. australes S080911_1). Putative maitotoxin-2 (p-MTX2) and maitotoxin-3 (p-MTX3) were identified in several other species, but confirmation was not possible because of the lack of reference material. Maitotoxin-4 was detected in all seven strains of G. excentricus examined, independently of their origin (Brazil, Canary Islands and Caribbean), and not detected in any other species. MTX4 may therefore serve as a biomarker for the highly toxic G. excentricus in the Atlantic area.
\end{abstract}


Keywords: Gambierdiscus excentricus; maitotoxin-4; bioguided fractionation; size-exclusion chromatography (LH-20); neuro-2a (N2a) assay; LC-HRMS/MS (Q-Tof 6550); LC-LRMS/MS (API4000 QTrap)

\section{Introduction}

Maitotoxin (MTX) (Figure 1) is among the most potent marine toxins identified to date, with an intraperitoneal (i.p.) lethal dose $50\left(\mathrm{LD}_{50}\right)$ in mice of $0.050 \mu \mathrm{g} \mathrm{kg}^{-1}$ [1]. Its oral potency, however, is much lower [2], probably due to low intestinal absorption caused by its high molecular weight and hydrophilicity. Consequently, MTX is primarily found in the tissues associated with the digestive tract of fish and is believed to play a role in ciguatera fish poisoning (CFP) if gut and liver tissues are consumed [3].

Maitotoxin was first detected in 1976 in the viscera of the bristletooth surgeonfish Ctenochaetus striatus (in Tahitian "maito", hence its name) collected in Tahiti (French Polynesia) and it was initially suspected of contributing to the diversity of ciguatera symptoms [4,5]. Eleven years later, the toxin was isolated from the dinoflagellate Gambierdiscus by Yasumoto, et al. [6] confirming the source of the toxin isolated from contaminated fish. Purified MTX exists as a white amorphous solid that is soluble in polar solvents (e.g., water, methanol and dimethylsulfoxide) and it is relatively stable in alkaline but not in acidic conditions. In aqueous solution, pure MTX tends to adhere to both glass and plastic surfaces $[7,8]$. When dissolved in methanol-water, MTX exhibits a single UV absorbance maximum at $230 \mathrm{~nm}$ [9] due to the presence of a conjugated diene at one extremity of the molecule $\left(\mathrm{C}_{2}-\mathrm{C}_{3}-\mathrm{C}_{4}-\mathrm{C}_{144}\right.$, Figure 1).

Experiments using purified MTX showed it causes a rapid influx of external $\mathrm{Ca}^{2+}$ and a steep increase of intracellular $\mathrm{Ca}^{2+}\left({ }_{\mathrm{i}} \mathrm{Ca}^{2+}\right)$ concentration in a wide variety of cells $[10,11]$. The $\mathrm{Ca}^{2+}$ influx elicited by MTX leads to numerous secondary events, including: depolarization in neuronal cells [12], phosphoinositide breakdown [13], smooth muscle contraction [14-16], induction of acrosome reaction in sperm [17-19], secretion of neurotransmitters (e.g., dopamine [20], noradrenaline [21,22], GABA [23]), hormones (e.g., insulin [24,25]) and inflammatory intermediates (e.g., arachidonic acid [26] and histamine [27]), formation or activation of large cytolytic/oncotic pores [28-30].

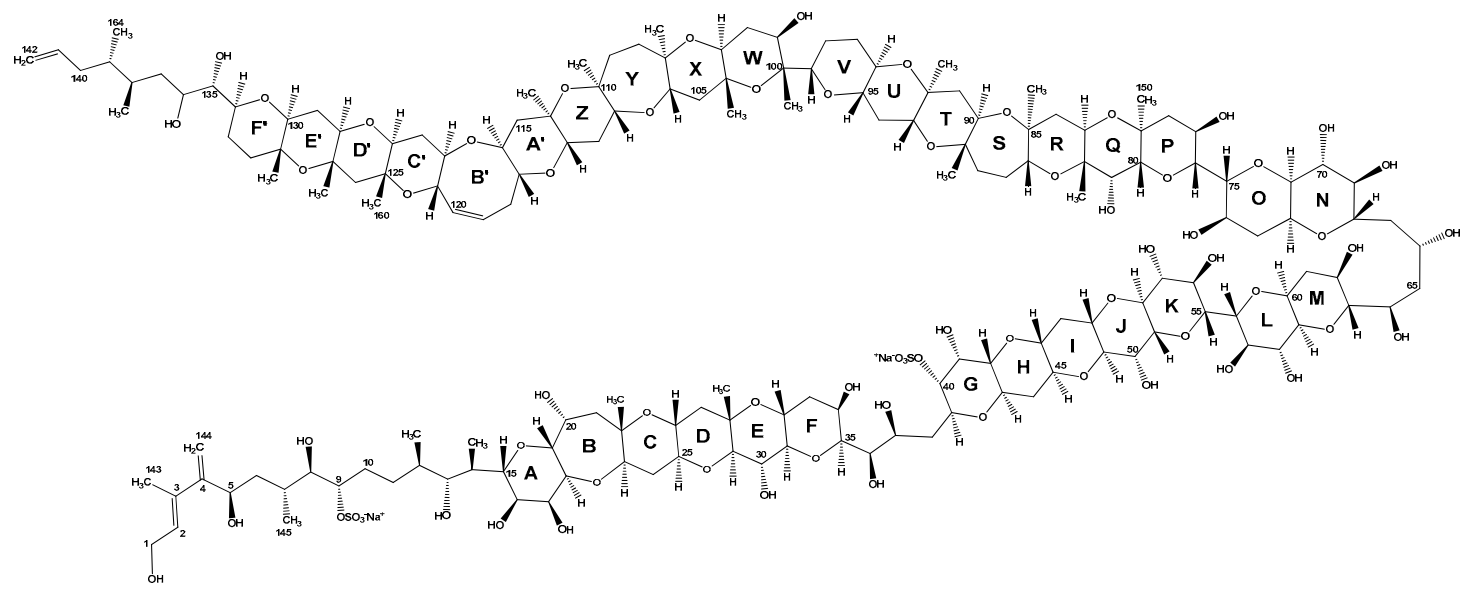

Figure 1. Absolute stereochemistry of maitotoxin (MTX) according to Sasaki et al. [31] and Nonomura et al. [32].

The complete chemical structure of MTX was elucidated in 1993 following purification from the Gambierdiscus strain (GII-1) isolated from Gambier Islands (French Polynesia) [1]. That analysis showed MTX is the largest non-polymeric marine toxin identified to date, consisting of a ladder-shaped cyclic 
polyether that is composed of 32 fused ether rings, 28 hydroxyl groups, 21 methyl groups, two sulfates and 98 chiral centers (molecular formula: $\mathrm{C}_{164} \mathrm{H}_{256} \mathrm{O}_{68} \mathrm{~S}_{2} \mathrm{Na}_{2}$, mono-isotopic mass = $3423.5811 \mathrm{Da}$ for the di-sodium salt). In 1996, the stereochemistry of the entire molecule was also assigned [31-33] (Figure 1). Gallimore and Spencer [34] contested the stereochemistry of the junction between J and K rings according to a mechanistic hypothesis for the biosynthesis of marine ladder-shaped polyethers. Subsequent studies by Nicolaou and Frederick [35] and Nicolaou, et al. [36] supported the originally assigned structure based on NMR spectroscopic data, computational studies and providing chemical synthesis and NMR analysis of the GHIJK ring system. X-ray crystal structure of MTX is needed to solve this controversy.

Though the effects of MTX at the cellular level are well characterized, its actual mode of action has not been fully elucidated. Initially, MTX was considered to be a specific activator of voltage-gated calcium channels [37-39]. In actuality, MTX increases ${ }_{i} \mathrm{Ca}^{2+}$ by activating a voltage-independent $\mathrm{Ca}^{2+}$ entry mechanism in the plasma membrane, without directly promoting the release of $\mathrm{Ca}^{2+}$ from intracellular storage compartments [40-42]. So far, MTX has been shown to activate non-selective ion channels, probably involving TRPC1 (transient receptor potential canonical 1) [40,41,43,44]. The activation of the sodium-calcium exchanger in reverse mode has also been observed in rat aortic smooth muscle cells [45]. The activation of the sodium-hydrogen exchanger equally appears to play a role in MTX cytotoxic activity in cortical neurons [46] and it may be a consequence of MTX-induced intracellular acidification, probably involving voltage-gated sodium channels [47]. Maitotoxin is also likely to convert the $\mathrm{Ca}^{2+}$-ATPase (PCMA) pump into a $\mathrm{Ca}^{2+}$-permeable non-selective ion channel, as demonstrated in PCMA-overexpressed Spodoptera frugiperda (Sf9) insect cells and human embryonic kidneys (HEK-293 cells) [48]. To date, it is unclear whether MTX directly interacts with any of these targets. Several research groups have postulated that MTX may bind a still undescribed MTX-receptor [35,42,49,50]. Since the specific molecular target of MTX is still unknown, its structure-activity relationship can only be inferred based on its NMR structural features and analogies with other ladder-shaped polyether toxins. Konoki, et al. [51] first hypothesized that the hydrophobic side of MTX (rings R through $\mathrm{F}^{\prime}$ ) penetrates the phospholipid bilayer of cell membranes and the hydrophilic portion of the molecule, presenting the polyhydroxy-groups and the two sulfate ester groups (rings A through Q), remains outside the cell (Figure 1). Modeling studies conducted by Reyes et al. [11] corroborate this hypothesis.

Sulfate ester groups seem to be critical for the biological activity of MTXs [52,53]. A study conducted by Murata et al. [52] in particular showed that desulfatation or hydrogenation of MTX significantly decreased its ability to induce $\mathrm{Ca}^{2+}$ influx or phosphoinositide breakdown in insulinoma or glioma cells. Murata, et al. [54] also hypothesized that a self-assemblage of four or more molecules could occur to form a pore on cell membranes for non-selective ion influx; however, this hypothesis has not been confirmed.

During the 1990s, two other MTX analogs, MTX2 and MTX3, were isolated by Holmes et al. [53,55]. Maitotoxin-2 (MTX2) was obtained from a single Australian Gambierdiscus strain from Queensland (NQ1) [55]. It had an i.p. $\mathrm{LD}_{50}$ in mice of $0.080 \mu \mathrm{g} \mathrm{kg}{ }^{-1}$ [53], i.e., 1.6-fold less toxic than MTX [1]. When dissolved in acetonitrile-water, MTX2 had a single UV absorbance maximum at $230 \mathrm{~nm}$ [53], identical to that reported for MTX in methanol-water [9]. The molecular structure of MTX2 has not been elucidated yet. Lewis, et al. [56] conducted LC-LRMS analyses of material isolated from strain NQ1 in ionspray ionization in positive ion acquisition mode $\left(\mathrm{IS}^{+}\right)$, ionspray ionization in negative ion acquisition mode $\left(\mathrm{IS}^{-}\right)$and fast atom bombardment ionization in negative ion acquisition mode $\left(\mathrm{FAB}^{-}\right)$and suggested that MTX2 is mono-sulfated with a molecular weight $(M W)$ of $3298 \mathrm{Da}$ (as mono-sodium salt).

Maitotoxin-3 (MTX3) was isolated from the Australian Gambierdiscus strain WC1/1 [53]. Maitotoxin-3 was found to be toxic in mice, inducing similar symptoms than those observed for MTX and MTX2, but scarcity of the purified compound did not permit the determination of MTX3 potency (i.p. $\mathrm{LD}_{50}$ in mice) [53]. On a reversed-phase column, MTX3 elutes earlier than MTX2 and later than MTX when using a linear gradient of acetonitrile/water [53]. When dissolved in acetonitrile-water, 
MTX3 had a UV spectrum composed of two peaks, a minor peak at $200 \mathrm{~nm}$ and a major peak at $235 \mathrm{~nm}$, slightly higher than MTX and MTX2 [53]. Lewis et al. [56] conducted LC-LRMS analyses of material isolated from strain WC1/1 in IS ${ }^{+}$acquisition mode. Their results suggested that MTX3 is di-sulfated with a $M W=1060.5 \mathrm{Da}$ (as di-sodium salt). The actual molecular structure of MTX3 has yet to be determined.

Since the molecular structures of MTX2 and MTX3 are still unknown, the only structural feature that is known to be common to the MTX class of toxins is the presence of (at least) one sulfate ester group. Desulfatation experiments conducted by Holmes and Lewis [53] on the three MTX analogs again suggested that at least one of the sulfate ester groups is critical for the bioactivity.

A schematic summary of the properties of three MTXs known to date with relevant chemical information is listed in Table 1. A recent study conducted by Lewis et al. [57] indicated that several strains of Gambierdiscus/Fukuyoa produce multiple MTX congeners, in one case more than four (G. belizeanus CCMP399), suggesting broader chemical diversity than what is known so far within MTX group. These analogs are not listed here since no further information beyond activity was provided in that study.

Table 1. List of the three MTXs known to date with relevant chemical information. Gambierdiscus sp. GII-1 was isolated from Gambier Islands (French Polynesia); Gambierdiscus sp. NQ1 from Queensland (Australia) and Gambierdiscus sp. WC1/1 from Australia. $\mathrm{FAB}^{-}$: fast atom bombardment ionization in negative ion acquisition mode. $\mathrm{IS}^{+}$: ionspray ionization in positive ion acquisition mode. IS $^{-}$: ionspray ionization in negative ion acquisition mode. UNKN: unknown.

\begin{tabular}{|c|c|c|c|c|c|c|c|}
\hline Name & Abbr. & Formula & Mass (Da) & Structural Studies & $\begin{array}{l}\text { Toxicity (i.p. } \mathrm{LD}_{50} \\
\text { in Mice, } \mu \mathrm{g} \mathrm{kg}^{-1} \text { ) }\end{array}$ & Source & Reference \\
\hline Maitotoxin & MTX & $\mathrm{C}_{164} \mathrm{H}_{256} \mathrm{O}_{68} \mathrm{~S}_{2} \mathrm{Na}_{2}$ & 3423.5811 & $\begin{array}{l}\text { IR, UV }\left(\lambda_{\max }=230 \mathrm{~nm}\right) \\
\text { LRMS } / \text { MS: FAB }{ }^{-} \text {NMR } \\
\text { with complete } \\
\text { stereochemistry }\end{array}$ & 0.050 & GII-1 & {$[1,31-33]$} \\
\hline Maitotoxin-2 & MTX2 & $\begin{array}{c}\text { UNKN } \\
\text { (mono-sodiated } \\
\text { salt of a molecule } \\
\text { containing one } \\
\text { sulfate ester) }\end{array}$ & 3298 & $\begin{array}{l}\mathrm{UV}\left(\lambda_{\max }=230 \mathrm{~nm}\right) \\
\text { LRMS: }^{+} \mathrm{IS}^{+}, \mathrm{IS}^{-}, \mathrm{FAB}^{-}\end{array}$ & 0.080 & NQ1 & [55] \\
\hline Maitotoxin-3 & MTX3 & $\begin{array}{l}\text { UNKN (di-sodiated } \\
\text { salt of a molecule } \\
\text { containing two } \\
\text { sulfate esters) }\end{array}$ & 1060.5 & $\begin{array}{c}\text { UV }\left(\lambda_{\max }=200\right. \\
235 \mathrm{~nm}) \text { LRMS: } \text { IS }^{+}\end{array}$ & UNKN & WC1/1 & [53] \\
\hline
\end{tabular}

Fifteen Gambierdiscus and three Fukuyoa species have been described in the past few decades [58-66]. As previously suggested [58], ongoing taxonomic studies being conducted by Tunin-Ley, et al. [67] also indicate that the biological diversity within these genera could be much higher than expected to date. The functional MTX toxicity for many of these species has been examined using erythrocyte lysis assay $[68,69]$ or neuroblastoma SH-SY5Y Ca ${ }^{2+}$ assay [57]. Of the species tested, G. excentricus, which was described from isolates obtained in the Canary Islands, exhibited much higher maito- and cigua (CTX)-toxicity than any other species known to occur in the Atlantic [61,69]. Its MTX- and CTX-toxicity were comparable to G. polynesiensis, the most toxic species isolated to date from the Pacific $[70,71]$. Due to its high MTX-toxicity, the aim of the present study was to characterize the MTX congeners produced by G. excentricus and to determine if they were the same or different from those previously identified. The approach was based on bioguided fractionation of the aqueous methanol fraction containing MTXs using size-exclusion chromatography (LH-20). Individual fractions were screened for MTX activity using the N2a cytotoxicity and $\mathrm{Ca}^{2+}$ flux functional assays. The MTX positive fractions were subjected to chemical analyses (LC-HRMS, LC-HRMS/MS and LC-LRMS/MS) to identify potential MTX congeners. Unfractionated methanolic extracts of a total of 44 strains representing one species of Fukuyoa and 11 species, one ribotype and one strain of Gambierdiscus whose species identity has yet to be determined were also screened at the same time. 
The results indicated G. excentricus produces a novel MTX congener, MTX4, which was not found in any of the other species tested.

\section{Results}

\subsection{Toxicity of the Aqueous Methanol Fractions (MSFs) from G. excentricus Strains VGO791 and VGO792}

The toxicity of the aqueous MeOH soluble fractions (MSFs) of strains VGO791 and VGO792 from the Canary Islands were assessed using the N2a cytotoxicity assay performed at the Phycotoxins Laboratory (Ifremer, Nantes, France). The assay was calibrated using a purified MTX standard, which induced mortality of the N2a cells in a concentration-dependent manner, with an $\mathrm{EC}_{50}$ of $158.5 \pm 5.4$ $(\mathrm{SD}, n=3) \mathrm{ng} \mathrm{MTX} \mathrm{mL}^{-1}$ (Figure S1). Strain VGO791 exhibited a toxin content of $0.65 \pm 0.13 \mathrm{ng}$ MTX equivalents (eq) cell $^{-1}$ and VGO792 a toxin content of $0.19 \pm 0.05 \mathrm{ng}$ MTX eq cell ${ }^{-1}$. Strain VGO791 was therefore 3.4-fold more toxic than VGO792. The results for VGO791 were in accordance with a previous study conducted by Fraga et al. [61], which estimated the toxicity of this strain at $0.60 \pm 0.24 \mathrm{MTX}^{\mathrm{eq}}$ cell $^{-1}$. In contrast, the toxicity estimated for VGO792 in the present study was 2.5-fold lower than that of $0.48 \pm 0.16 \mathrm{ng}$ MTX eq cell ${ }^{-1}$ obtained by Fraga et al. [61].

\subsection{Screening of Fractionated G. excentricus Extracts Using Neuroblastoma N2a Assays}

\subsubsection{N2a Cytotoxicity Assay}

The fractionation of the extracted MSF sample from strain VGO791 was accomplished using size-exclusion chromatography (SEC, LH-20). The fractions containing MTX activity consistently eluted within an elution volume $\left(V_{\mathrm{e}}\right)$ range of $12.5-27.5 \mathrm{~mL}$. The most toxic fractions were found in $V_{\mathrm{e}}=15.0-17.5 \mathrm{~mL}$ (up to $58.8 \%$ total cytotoxicity) (Figure 2a). Similarly, toxic fractions from strain VGO792 eluted in the range of $V_{\mathrm{e}}=13.0-26.0 \mathrm{~mL}$, with the most toxic fractions being fraction $V_{\mathrm{e}}=15.0-16.0 \mathrm{~mL}$ (up to $29.8 \%$ total cytotoxicity) and $V_{\mathrm{e}}=16.0-17.0 \mathrm{~mL}$ (up to $23.3 \%$ total cytotoxicity) (Figure 2b). Fractions of VGO792 corresponding to $V_{\mathrm{e}}=23.0-26.0 \mathrm{~mL}$ showed slight cytotoxic activity (N2a cell survival $\sim 80-90 \%$ ) only when the highest concentration of cell extracts was tested (150 Gambierdiscus cell eq per well). Serial dilutions of the latter fractions contained no detectable toxicity as measured using the N2a assay ( $\mathrm{N} 2$ a cell survival $>90 \%$ ). Consequently, sigmoidal dose-response curves could not be plotted and $\mathrm{EC}_{50}$ values could not be calculated for quantification purposes for the low toxicity fractions.

The N2a cytotoxicity assay showed that toxic compound(s) eluted right after the total exclusion volume of the LH-20 column (i.e., approximately $30 \%$ of bed volume, $12.4 \mathrm{~mL}$ ). LH-20 chromatography separates compounds with $M W \leq 5000$ Da according to their size (i.e., smaller compounds elute later than bigger ones) meaning the toxic compound(s) from these strains are likely to fall in the range of 3000-3500 Da, consistent with the molecular weight of MTX.

\subsubsection{N2a Calcium Flux Assay}

The N2a-based high-content screening (HCS) assay for calcium $\left(\mathrm{Ca}^{2+}\right)$ flux was performed at the ANSES Laboratory (Fougères, France). $\mathrm{A} \mathrm{Ca}^{2+}$ flux assay was used in this study to measure changes in internal $\mathrm{Ca}^{2+}$ concentration in N2a cells. The assay works by loading cells with a fluorescent dye, in this case Fluo-4-AM, whose fluorescence changes as a function of intracellular $\mathrm{Ca}^{2+}\left({ }_{i} \mathrm{Ca}^{2+}\right)$ concentration. Maitotoxin standard elicited an increase of ${ }_{i} \mathrm{Ca}^{2+}$ in N2a cells in a concentration-dependent manner (Figure S2). Since MTX induces influx of $\mathrm{Ca}^{2+}$ into cells, a significant increase in fluorescence is consistent with the presence of MTX (Section 4.5.2). Results were expressed as a fold of intensity compared to control treatment ( $5 \% \mathrm{MeOH}$ in FCS-free N2a medium). 

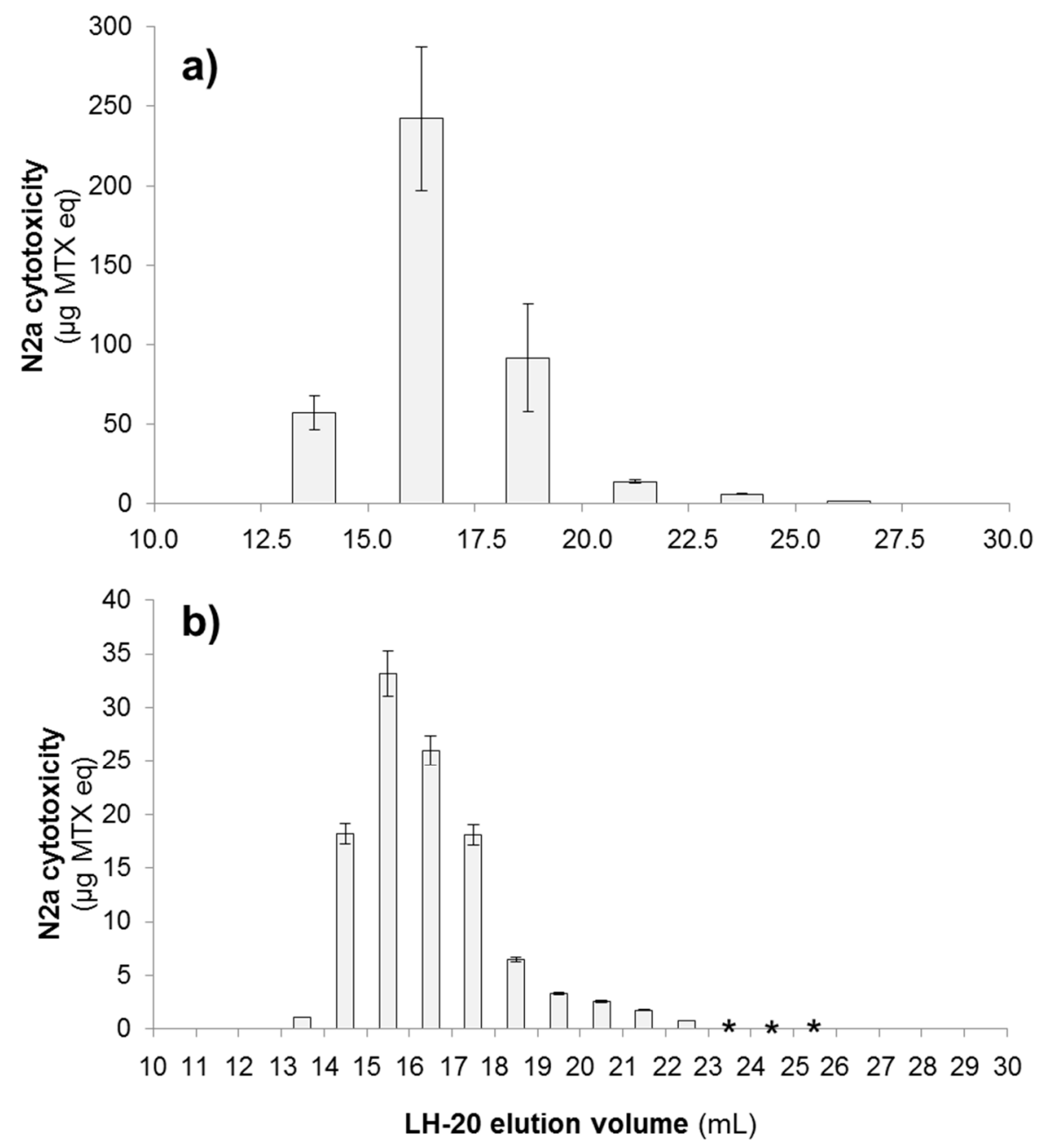

Figure 2. Estimated maitotoxin equivalents ( $\mu \mathrm{g}$ MTX eq) in the LH-20-fractionated MSFs of G. excentricus strains VGO791 and VGO792 measured using the N2a cytotoxicity assay. (a) MTX eq of the individual $2.5 \mathrm{~mL}$-fractions for G. excentricus VGO791 (2.20 million cells extracted in original MSF, approximately half of which was loaded on the LH-20 column). (b) MTX eq of the individual $1 \mathrm{~mL}$-fractions for G. excentricus VGO792 (2.16 million cells extracted in original MSF, approximately half of which was loaded on the LH-20 column). The x-axis is expressed as the total elution volume $(\mathrm{mL})$ that has passed through the LH-20 column when each fraction was collected. Error bars represent assay variability (standard deviation, SD) measured by running extracts in three separate assays. In each assay, three separate wells were used for assaying each fraction. Cytotoxicity was observed only in LH-20 fractions within an elution volume $\left(V_{\mathrm{e}}\right)$ range of (a) $V_{\mathrm{e}}=12.5-27.5 \mathrm{~mL}$ and (b) $V_{\mathrm{e}}=13.0-26.0 \mathrm{~mL}$. Asterisks $\left.{ }^{*}\right)$ in (b) indicate detection of non-quantifiable cytotoxicity in fractions with $V_{\mathrm{e}}=23.0-26.0 \mathrm{~mL}$. Fractions corresponding to $V_{\mathrm{e}}<10.0 \mathrm{~mL}$ and $V_{\mathrm{e}}>30.0 \mathrm{~mL}$ are not shown because no cytotoxicity was observed in those fractions.

The crude extract (CE) and the MSF of G. excentricus VGO791 increased ${ }_{\mathrm{i}} \mathrm{Ca}^{2+}$ levels in N2a cells up to the saturation level (data not shown), indicating the presence of compounds exhibiting activity similar to MTX. Only the six LH-20 fractions of MSF falling within a $V_{\mathrm{e}}$ range of $12.5-27.5 \mathrm{~mL}$ showed an increase in ${ }_{\mathrm{i}} \mathrm{Ca}^{2+}$ levels of between 1.2- and 1.8-fold (Figure 3), suggesting that MTX-related compound(s) mostly eluted in these fractions. These findings are consistent with the results obtained by the N2a cytotoxicity assay (Section 2.2.1). 


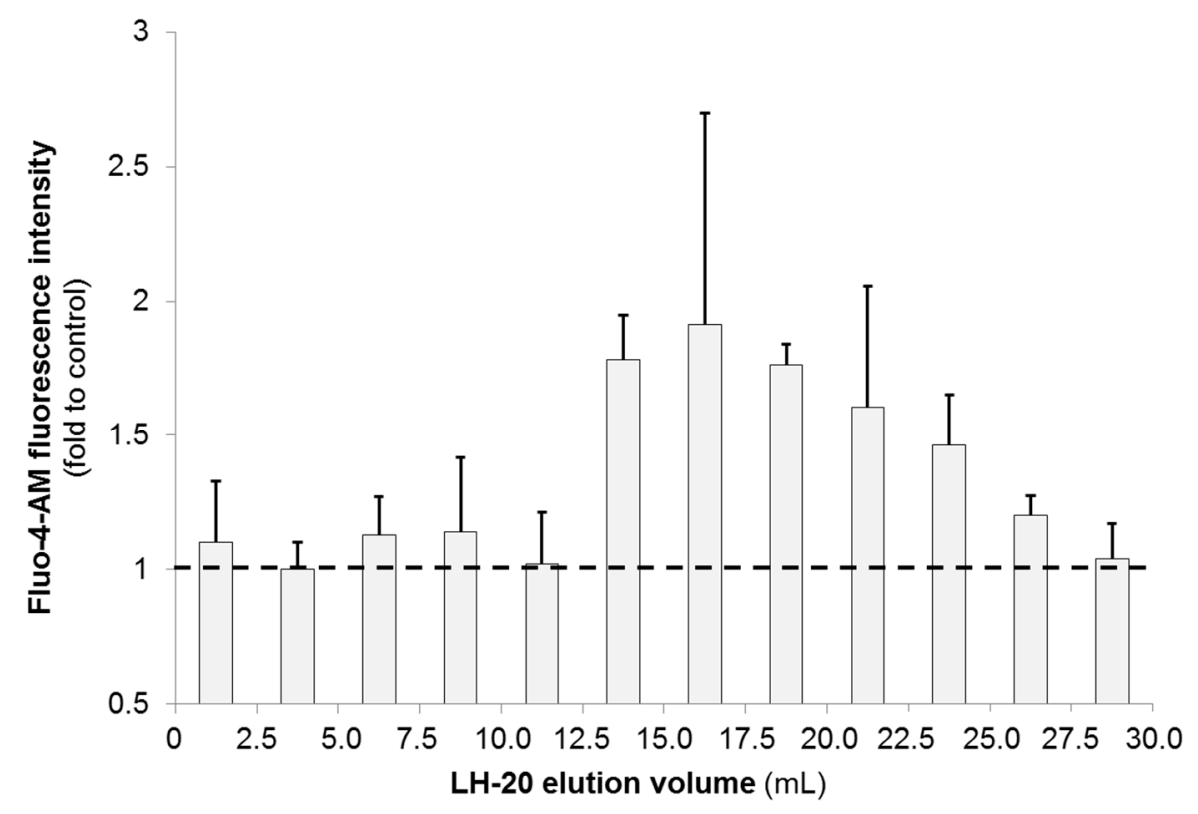

Figure 3. Calcium $\left(\mathrm{Ca}^{2+}\right)$ influx into N2a cells induced by LH-20 fractions of G. excentricus VGO791 (MSF sample). $\mathrm{Ca}^{2+}$ flux was measured using fluorescence of Fluo-4-AM (488 nm). Fluo-4-AM fluorescence was expressed as a fold of intensity compared to the control wells (horizontal dashed line). Error bars represent assay variability (standard deviation, SD) measured by running extracts in three separate assays. In each assay, three separate wells were used for assaying each fraction. $\mathrm{Ca}^{2+}$ influx was observed only in LH-20 fractions corresponding to an elution volume $\left(V_{\mathrm{e}}\right)$ of 12.5-27.5 mL. Fractions eluting after a $V_{\mathrm{e}}$ of $30 \mathrm{~mL}$ were omitted because they exhibited no MTX-induced fluorescence changes.

2.3. Liquid Chromatography Coupled to Full-Scan High Resolution Mass Spectrometry and Discovery of a New Maitotoxin Analog

The Molecular Feature Extraction (MFE) algorithm of the Agilent MassHunter Qualitative Analysis software allows for retreatment of raw data of non-targeted HRMS analysis (Q-Tof 6550). Extracted compound chromatograms acquired in negative ionization mode (negative ECCs) of G. excentricus VGO791 confirmed that liquid-liquid partitioning and size-exclusion chromatography purification steps considerably reduced data complexity. More than one thousand features were detected in the crude extract, while only 40 features (3\%) were present in the most toxic LH-20 fraction $\left(V_{\mathrm{e}}=15.0-17.5 \mathrm{~mL}\right)$ (Figure 4). Similarly, MFE results for G. excentricus VGO792 also exhibited a reduction of data complexity from more than five thousands features to only $239(4.3 \%)$ in the most toxic LH-20 fraction of MSF $\left(V_{\mathrm{e}}=15.0-16.0 \mathrm{~mL}\right)$, data not shown. These results indicate that fractionation via liquid-liquid partitioning and size-exclusion chromatography (LH-20) is a suitable strategy for Gambierdiscus toxin purification. In particular, LH-20 is an efficient clean-up step for high molecular weight compounds as it allows for sufficient purification for individual compounds to be identified as potential MTX congeners.

Among the occurring negative ions present in the negative mode ECCs of the most toxic LH-20 fractions of G. excentricus VGO791 and VGO792, only one bi-charged anion presented, like MTX, an $m / z$ ratio $>1500$. This compound possesses a retention time close to that of MTX ( $\triangle R T=+0.49 \mathrm{~min})$. Interestingly, it was detected only in the most toxic LH-20 fractions of both strains (as well as in their MSF and crude extract) and was not detected in non-toxic fractions. Thus, the presence of this compound in toxic fractions only, along with similar MS and chromatographic behavior as MTX, suggested that the compound could be a novel MTX analog and hence it was named maitotoxin-4 (MTX4). 

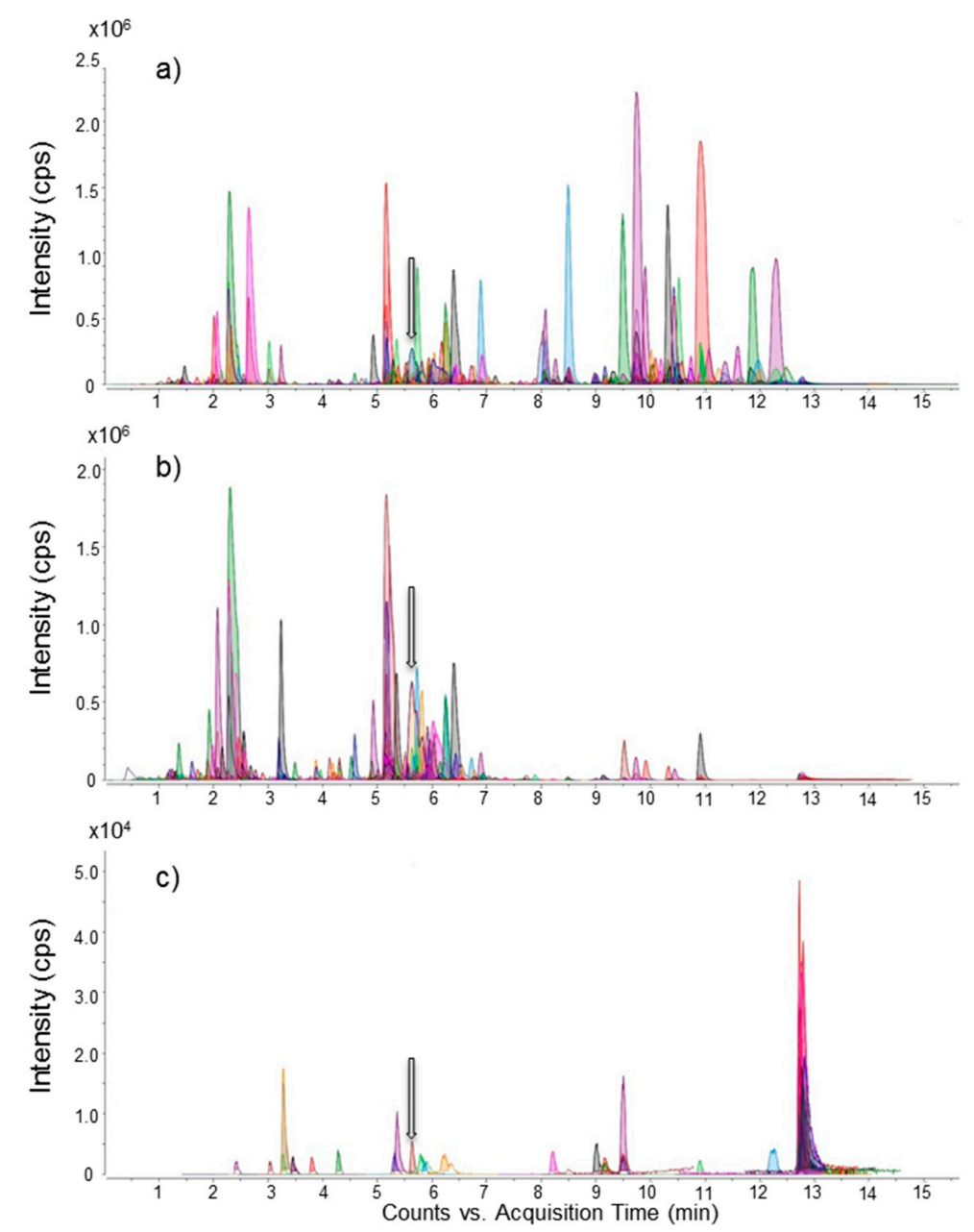

Figure 4. Negative Extracted Compound Chromatograms (ECCs) of G. excentricus VGO791 samples: (a) crude extract; (b) aqueous methanol soluble fraction (MSF); (c) the most toxic LH-20 fraction $\left(V_{\mathrm{e}}=15.0-17.5 \mathrm{~mL}\right)$ of MSF. The different color peaks represent unique features. The highlighted grey arrow indicates the peak corresponding to maitotoxin-4 (MTX4).

\subsection{Mass Spectral Comparison of Maitotoxin-4 with Maitotoxin}

\subsubsection{Negative Mode HRMS Spectra}

Maitotoxin-4 (MTX4) had a spectral profile similar to MTX. Maitotoxin-4 spectra originate from the pre-purified LH-20 fraction $\left(V_{\mathrm{e}}=15.0-16.0 \mathrm{~mL}\right)$ of G. excentricus VGO792. The assigned negative HRMS ion species (accurate mono-isotopic $m / z$ ) for MTX and MTX4 are listed in Table 2.

Both MTX and MTX4 presented: (i) bi-charged molecular anions $[\mathrm{M}-2 \mathrm{H}]^{2-}$, with accurate mono-isotopic $m / z$ of 1688.8027 for MTX ( $\Delta$ ppm: -0.8 ) and 1645.2357 for MTX4 and (ii) tri-charged molecular anions $[\mathrm{M}-3 \mathrm{H}]^{3-}$, with accurate mono-isotopic $m / z$ of 1125.5334 for MTX $(\Delta \mathrm{ppm}$ : -1.4) and 1096.4889 for MTX4 (Figure 5a,b). Hence, MTX4 presents a lower mass than the MTX standard: 3292.4860 (MTX4 accurate calculated mass, free acid form) versus 3379.6172 (MTX theoretical exact mass, free acid form), $\Delta \mathrm{M}=87.1312$. For MTX only, it was also possible to observe the quadri-charged molecular anion $[\mathrm{M}-4 \mathrm{H}]^{4-}$, with accurate mono-isotopic $m / z$ of 843.8989 ( $\Delta$ ppm: -2.1) (Figure 5a). Further, the following adducts (accurate mono-isotopic $\mathrm{m} / \mathrm{z}$ ) could be assigned: $[\mathrm{M}+\mathrm{Na}-3 \mathrm{H}]^{2-}=1699.7914$ for MTX $(\Delta \mathrm{ppm}:+0.5)$ and 1656.2256 for MTX4; $[\mathrm{M}+2 \mathrm{Na}-4 \mathrm{H}]^{2-}=1710.7814$ for MTX $(\Delta \mathrm{ppm}:+1.1)$ and 1667.2075 for MTX4 (Figure 5a,b). In the negative mode HRMS spectrum of MTX4, two additional peaks were observed, with accurate 
mono-isotopic $m / z$ of $1356.6470(z=2$, bi-charged anion) and $904.0954(z=3$, tri-charged anion), suggesting either that some fragmentation occurred in the ESI source or that co-elution occurred during the chromatographic separation (Figure $5 b$ ).

Table 2. List of the assigned negative HRMS ion species for MTX and MTX4. MTX4 spectra originate from the pre-purified LH-20 fraction $\left(V_{\mathrm{e}}=15.0-16.0 \mathrm{~mL}\right)$ of $G$. excentricus VGO792. The $\mathrm{m} / \mathrm{z}$ values in the table correspond to the accurate mono-isotopic $m / z$. ND: not detected. UNKN: unknown.

\begin{tabular}{cccc}
\hline & & MTX & MTX4 \\
\hline Elemental formula (free acid form) & & $\mathrm{C}_{164} \mathrm{H}_{258} \mathrm{O}_{68} \mathrm{~S}_{2}$ & $\mathrm{UNKN}$ \\
\hline Retention time $(R T, \mathrm{~min})$ & & $4.09 \mathrm{~min}$ & $4.58 \mathrm{~min}$ \\
\hline Ion species & {$[\mathrm{M}-2 \mathrm{H}]^{2-}$} & $1688.8027(\Delta \mathrm{ppm}:-0.8)$ & 1645.2357 \\
(accurate mono-isotopic $m / z)$ & {$[\mathrm{M}+\mathrm{Na}-3 \mathrm{H}]^{2-}$} & $1699.7914(\Delta \mathrm{ppm}:+0.5)$ & 1656.2256 \\
& {$[\mathrm{M}-3 \mathrm{Na}-4 \mathrm{H}]^{3-}$} & $1710.7814(\Delta \mathrm{ppm}:+1.1)$ & 1667.2075 \\
& {$[\mathrm{M}-4 \mathrm{H}]^{4-}$} & $843.8989(\Delta \mathrm{ppm}:-2.1)$ & 1096.4889 \\
\hline
\end{tabular}
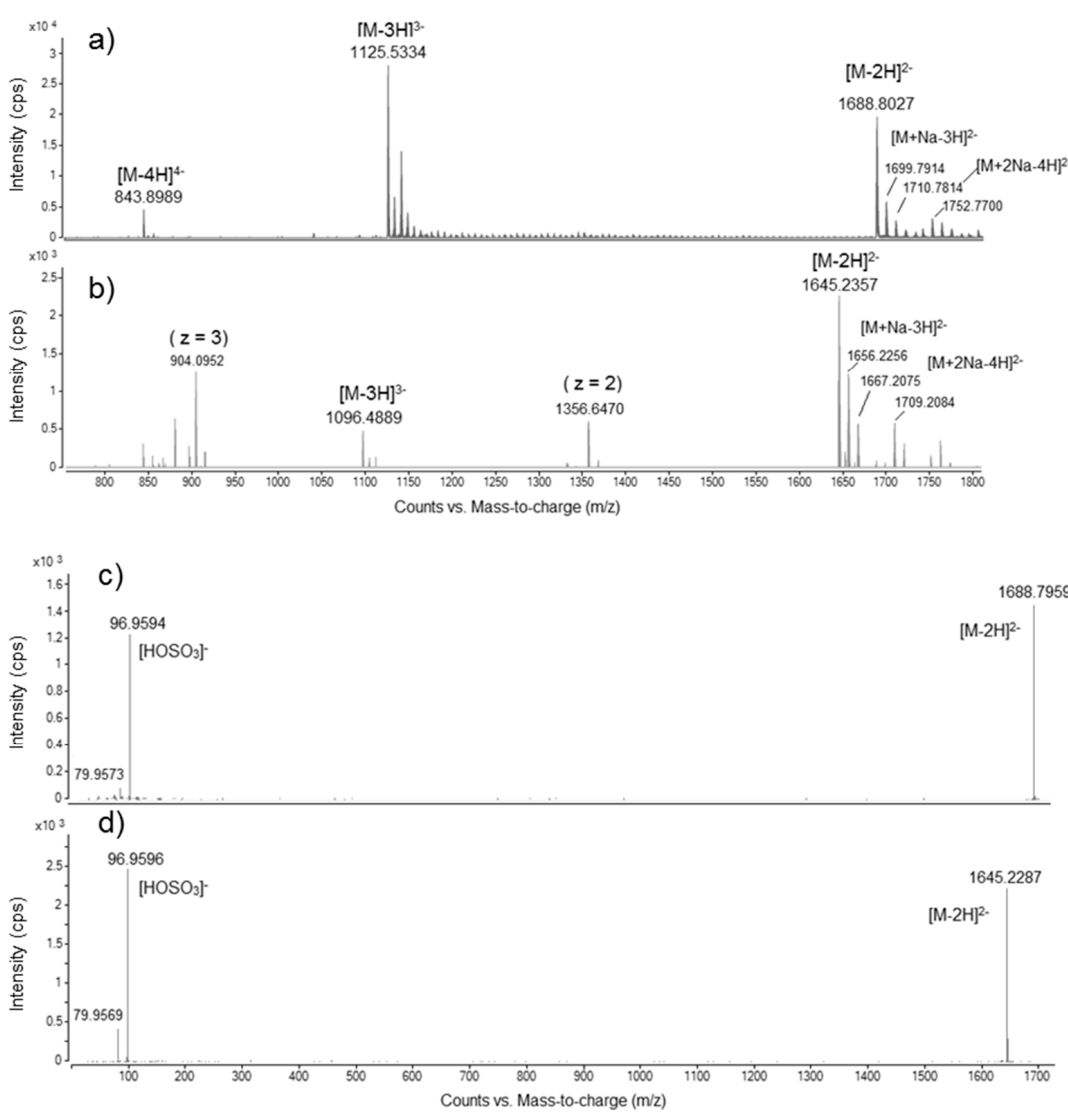

Figure 5. Raw spectra in full scan, negative ion acquisition mode HRMS of (a) maitotoxin (MTX) and (b) maitotoxin-4 (MTX4) acquired over an $\mathrm{m} / \mathrm{z}$ range from 100 to 3200, focused on the $\mathrm{m} / \mathrm{z}$ range from 800 to 1800 . Maitotoxin-4 spectra originate from the pre-purified LH-20 fraction $\left(V_{\mathrm{e}}=15.0-16.0 \mathrm{~mL}\right)$ of G. excentricus VGO792. Note the presence of bi-charged and tri-charged ion clusters for both MTX and MTX4. Negative mode ESI product ion spectra of bi-charged molecular anions of (c) MTX and (d) MTX4 at an average of three collision energies (CE): 50, 100 and $200 \mathrm{eV}$ over an $\mathrm{m} / \mathrm{z}$ range from 25 to 3200 , focused on the $m / z$ range from 25 to 1700 . Note the same product ion $\left[\mathrm{HOSO}_{3}\right]^{-}$for both MTX and MTX4. Nota bene: the $m / z$ values highlighted in the figure correspond to the accurate, i.e., measured mono-isotopic $m / z$. 


\subsubsection{Negative Mode HRMS/MS Spectra}

Maitotoxin-4 (MTX4) was further analyzed using Collision Induced Dissociation in Q-Tof targeted MS/MS mode (HRMS/MS). Maitotoxin-4 spectra originate from the pre-purified LH-20 fraction $\left(V_{\mathrm{e}}=15.0-16.0 \mathrm{~mL}\right)$ of G. excentricus VGO792. Accurate mass data and isotopic distributions for the precursor and product ions of MTX4 were compared to spectral data of the reference compound, MTX, obtained in identical experimental conditions.

HRMS/MS fragmentation of the bi-charged molecular anion $\left([\mathrm{M}-2 \mathrm{H}]^{2-}\right)$ of MTX and MTX4 showed that the two molecules share the same product ion at an average $m / z$ of $96.9593 \pm$ SD 0.0003 $(n=4)$ when using a collision energy (CE) $\geq 100 \mathrm{eV}$ (Figure $5 \mathrm{c}, \mathrm{d})$. This fragment corresponds to the hydrogenated sulfate anion $\left[\mathrm{HOSO}_{3}\right]^{-}(\Delta \mathrm{ppm}:+8.3)$. No other characteristic fragment ion has been found at any of the collision energies tested.

\subsection{Quantification of MTX4 via LC-LRMS/MS}

The limit of detection (LOD) and the limit of quantification (LOQ) of the MRM transition $[\mathrm{M}-2 \mathrm{H}]^{2-} \rightarrow[\mathrm{M}-2 \mathrm{H}]^{2-}$ of MTX chosen for quantification purpose, were, respectively, $0.64 \mu \mathrm{g} \mathrm{mL}^{-1}$ and $2.12 \mu \mathrm{g} \mathrm{mL}^{-1}$. LOD and LOQ of MTX4 were assumed being the same of MTX. The LOD and the LOQ of the MRM transition $[\mathrm{M}-3 \mathrm{H}]^{3-} \rightarrow[\mathrm{M}-3 \mathrm{H}]^{3-}$ of MTX were, respectively, $0.12 \mu \mathrm{g} \mathrm{mL}{ }^{-1}$ and $0.39 \mu \mathrm{g} \mathrm{mL}^{-1}$. As shown in Figure $5 \mathrm{a}$, the tri-charged molecular anion of MTX gave a more intense response than the bi-charged molecular anion in our analytical conditions. Nevertheless, that was not the case for MTX4 (Figure 5b). Although the higher LOD and LOQ, the MRM transition $[\mathrm{M}-2 \mathrm{H}]^{2-} \rightarrow[\mathrm{M}-2 \mathrm{H}]^{2-}$ was chosen for quantification instead of the MRM transition $[\mathrm{M}-3 \mathrm{H}]^{3-} \rightarrow[\mathrm{M}-3 \mathrm{H}]^{3-}$.

Table 3 presents the results of (i) the amount of MTX4 present in crude extracts from approximately 2.2 million cells of G. excentricus VGO791 and VGO792 and (ii) the amount of MTX4 remaining after the subsequent liquid-liquid partitioning and LH-20 chromatography purification steps. The quantities of MTX4 were estimated using multiple reaction monitoring (MRM) mode on LC-LRMS/MS as described in Section 4.6.2. The amounts of MTX4 present were expressed as $\mu \mathrm{g}$ MTX eq, assuming an equimolar response of MTX4 and MTX in MS. The efficiency of each purification step was expressed in percent recovery relative to the amount of MTX in the crude extract. The combination of the two purification steps allowed for a percent recovery of 72\% for VGO791 and 70\% for VGO792 if all the toxic fractions with a concentration of MTX4 > LOQ were combined (Table 3).

Table 3. Amounts of MTX4 present in crude extract from approximately 2.2 million cells of G. excentricus VGO791 and VGO792 and the amounts of toxin remaining after the subsequent liquid-liquid partitioning and LH-20 chromatography purification steps. The MTX4 estimates were obtained using multiple reactions monitoring (MRM) mode on LC-LRMS/MS. Quantification of MTX4 was based on the MRM transition $1646.2 \rightarrow 1646.2 \mathrm{~m} / z\left([\mathrm{M}-2 \mathrm{H}]^{2-} \rightarrow[\mathrm{M}-2 \mathrm{H}]^{2-}\right)$ using MTX as the reference standard, quantified using the MRM transition $1689.8 \rightarrow 1689.8 \mathrm{~m} / \mathrm{z}\left([\mathrm{M}-2 \mathrm{H}]^{2-} \rightarrow[\mathrm{M}-2 \mathrm{H}]^{2-}\right)$. Amounts of MTX4 were therefore expressed in $\mu \mathrm{g}$ MTX eq, assuming an equimolar response of MTX4 and MTX in MS. * MSF: aqueous methanol soluble fraction.

\begin{tabular}{|c|c|c|c|c|}
\hline Strain Name & Sample Name & $\begin{array}{c}\text { MTX4 } \\
(\mu \mathrm{g} \text { MTX eq) }\end{array}$ & $\begin{array}{c}\text { \% Recovery } \\
\text { (Liquid-Liquid Partitioning) }\end{array}$ & $\begin{array}{l}\text { \% Recovery } \\
\text { (LH-20) }\end{array}$ \\
\hline \multirow{10}{*}{$\begin{array}{c}\text { Gambierdiscus excentricus } \\
\text { VGO791 }\end{array}$} & Crude extract & 160.1 & $100 \%$ & \\
\hline & \multicolumn{4}{|c|}{ Liquid-liquid partitioning of crude extract } \\
\hline & MSF * $^{*}$ & 137.4 & $85.8 \%$ & \\
\hline & \multicolumn{4}{|c|}{ Size-exclusion chromatography (LH-20) of MSF sample } \\
\hline & $V_{\mathrm{e}}=12.5-15.0 \mathrm{~mL}$ & 19.1 & & $13.9 \%$ \\
\hline & $V_{\mathrm{e}}=15.0-17.5 \mathrm{~mL}$ & 69.2 & & $50.4 \%$ \\
\hline & $V_{\mathrm{e}}=17.5-20.0 \mathrm{~mL}$ & 19.0 & & $13.8 \%$ \\
\hline & $V_{\mathrm{e}}=20.0-22.5 \mathrm{~mL}$ & 4.5 & & $3.3 \%$ \\
\hline & $V_{\mathrm{e}}=22.5-25.0 \mathrm{~mL}$ & 1.5 & & $1.1 \%$ \\
\hline & $V_{\mathrm{e}}=25.0-27.5 \mathrm{~mL}$ & 1.2 & & $0.9 \%$ \\
\hline
\end{tabular}


Table 3. Cont.

\begin{tabular}{|c|c|c|c|c|}
\hline Strain Name & Sample Name & $\begin{array}{c}\text { MTX4 } \\
(\mu \mathrm{g} \text { MTX eq) }\end{array}$ & $\begin{array}{c}\% \text { Recovery } \\
\text { (Liquid-Liquid Partitioning) }\end{array}$ & $\begin{array}{l}\text { \% Recovery } \\
\text { (LH-20) }\end{array}$ \\
\hline & Crude extract & 43.1 & $100 \%$ & \\
\hline & \multicolumn{4}{|c|}{ Liquid-liquid partitioning of crude extract } \\
\hline & $\mathrm{MSF}^{*}$ & 34.2 & $79.4 \%$ & \\
\hline & \multicolumn{4}{|c|}{ Size-exclusion chromatography (LH-20) of MSF sample } \\
\hline & $V_{\mathrm{e}}=13.0-14.0 \mathrm{~mL}$ & 0.6 & & $1.7 \%$ \\
\hline & $V_{\mathrm{e}}=14.0-15.0 \mathrm{~mL}$ & 4.6 & & $13.5 \%$ \\
\hline Gambierdiscus excentricus & $V_{\mathrm{e}}=15.0-16.0 \mathrm{~mL}$ & 10.3 & & $30.1 \%$ \\
\hline \multirow[t]{10}{*}{ VGO792 } & $V_{\mathrm{e}}=16.0-17.0 \mathrm{~mL}$ & 6.2 & & $18.0 \%$ \\
\hline & $V_{\mathrm{e}}=17.0-18.0 \mathrm{~mL}$ & 3.3 & & $9.6 \%$ \\
\hline & $V_{\mathrm{e}}=18.0-19.0 \mathrm{~mL}$ & 1.8 & & $5.3 \%$ \\
\hline & $V_{\mathrm{e}}=19.0-20.0 \mathrm{~mL}$ & 1.2 & & $3.4 \%$ \\
\hline & $V_{\mathrm{e}}=20.0-21.0 \mathrm{~mL}$ & 0.8 & & $2.5 \%$ \\
\hline & $V_{\mathrm{e}}=21.0-22.0 \mathrm{~mL}$ & 0.6 & & $1.9 \%$ \\
\hline & $V_{\mathrm{e}}=22.0-23.0 \mathrm{~mL}$ & 0.6 & & $1.7 \%$ \\
\hline & $V_{\mathrm{e}}=23.0-24.0 \mathrm{~mL}$ & $<\mathrm{LOQ}$ & & \\
\hline & $V_{\mathrm{e}}=24.0-25.0 \mathrm{~mL}$ & $<\mathrm{LOQ}$ & & \\
\hline & $V_{\mathrm{e}}=25.0-26.0 \mathrm{~mL}$ & $<$ LOQ & & \\
\hline
\end{tabular}

\subsection{Relationship between N2a Cytotoxicity and MTX4 Content}

The MTX contents of MSFs estimated via N2a cytotoxicity assay were: $1427 \pm 289 \mu \mathrm{g}$ MTX eq for G. excentricus VGO791 (2.20 million cells) and $408 \pm 110 \mu \mathrm{g}$ MTX eq for G. excentricus VGO792 (2.16 million cells). This estimation is, respectively, 10.4- and 11.8-fold higher than the MTX4 content estimated via LC-LRMS/MS (137.4 and $34.2 \mu \mathrm{g}$ MTX eq, respectively, Section 2.5).

Six LH-20 fractions of VGO791 $\left(V_{\mathrm{e}}=12.5-27.5 \mathrm{~mL}\right)$ and ten LH-20 fractions of VGO792 $\left(V_{\mathrm{e}}=13.0-23.0 \mathrm{~mL}\right)$ contained measurable quantities of (i) MTX equivalent toxicity ( $\mu$ g MTX eq, starting with an initial crude extract of $\sim 2.2$ million cells) as measured using the N2a cytotoxicity assay (Section 2.2.1) and (ii) MTX4 ( $\mu$ g MTX eq) using LC-LRMS/MS (Section 2.5). Toxin content estimated with the N2a cytotoxicity assay was plotted against MTX4 quantification performed using LC-LRMS/MS. The linear correlation between the amount of MTX equivalents (N2a cytotoxicity assay) and the MTX4 content (LC-LRMS/MS) among the 16 toxic LH-20 fractions (slope: 3.498, $R^{2}: 0.986$, $n=16)$ suggests that MTX4 is a major contributor agent for the MSF-toxicity of both G. excentricus strains (Figure 6).

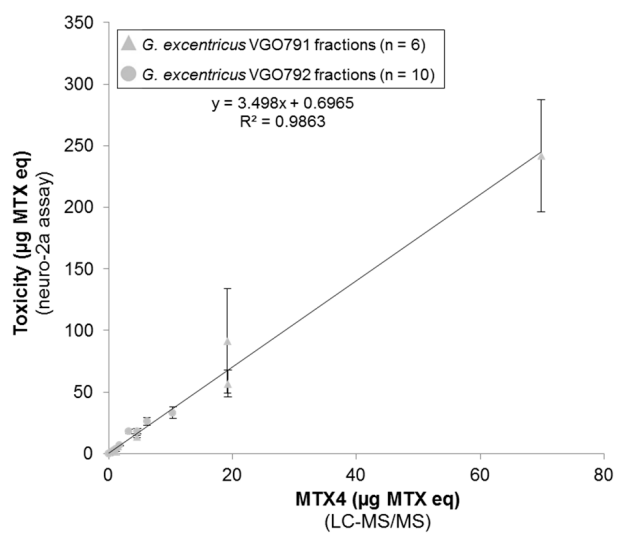

Figure 6. Linear correlation between the MTX equivalents (N2a cytotoxicity assay) and the MTX4 content (LC-LRMS/MS) in all LH-20 fractions containing quantifiable amounts of the two strains of G. excentricus VGO791 $(n=6)$ and VGO792 $(n=10)$. Results are expressed in $\mu$ g MTX eq, assuming an equimolar response of MTX4 and MTX in MS. Error bars represent assay variability (standard deviation, SD) measured by running extracts in three separate assays. In each of these assays, three separate wells were used for assaying each fraction. The MTX4 LC-LRMS/MS determinations were not replicated. 


\subsection{Diversity of MTX Analogs among Gambierdiscus and Fukuyoa Strains}

A total of two strains of Fukuyoa (one species, F. ruetzleri) and 42 strains of Gambierdiscus representing 11 species, one ribotype and one strain of Gambierdiscus whose identity has yet to be determined, were screened for the presence of MTX analogs using the LC-LRMS/MS conditions described in Section 4.6.2.

The LC-LRMS/MS method consisted of searching for several MRM transitions of different parent ions pointing towards the hydrogenated sulfate anion $\left[\mathrm{HOSO}_{3}\right]^{-}(96.9 \mathrm{~m} / \mathrm{z})$. The parent ions for MTX and MTX4 were chosen from the negative ionization mode HRMS analysis conducted in this study (Section 2.4.1). More precisely, the third isotopic peak $(M+2)$ was chosen because it was the most intense (i.e., $1689.8 \mathrm{~m} / \mathrm{z}$ and $1126.2 \mathrm{~m} / \mathrm{z}$ for MTX and $1645.2 \mathrm{~m} / \mathrm{z}$ and $1097.1 \mathrm{~m} / \mathrm{z}$ for MTX4). In the absence of MS/MS data on MTX2 and MTX3, parent ions were selected from the literature [56,72]. For MTX2, bi-charged and tri-charged adducts with $\mathrm{Na}^{+}$and $\mathrm{K}^{+}$have been reported in a previous study [56] and these have been used for LRMS/MS analysis. Furthermore, the bi-charged and tri-charged molecular anions have been searched assuming similar MS behavior of MTX4 compared to MTX. Thus, both molecular $\left([\mathrm{M}-2 \mathrm{H}]^{2-}\right.$ and $[\mathrm{M}-3 \mathrm{H}]^{3-}$ ) and pseudomolecular anions (i.e., $\mathrm{Na}^{+}$and $\mathrm{K}^{+}$adducts) have been searched for. Maitotoxin-3 is assumed to be di-sulfated [56] and was tentatively detected in previous studies using the loss of sulfate from the mono-charged mono-sodium adduct, i.e., the MRM transition $[\mathrm{M}+\mathrm{Na}-2 \mathrm{H}]^{-} \rightarrow\left[\mathrm{HOSO}_{3}\right]^{-}(m / z$ 1037.6 $\rightarrow 96.9)[59,64,66,71-74]$. With the aim of increasing selectivity, in this study the mono-charged and bi-charged molecular anions, as well as the mono-charged di-sodium adduct have been searched for, assuming similar MS behavior as that of MTX and MTX4 (Section 4.6.2).

Results are summarized in Table 4. Limits of detection (LODs) in Table 4 have been calculated from the number of cells extracted, specified in Table 5. Maitotoxin was found only in one strain, G. australes S080911_1, at a concentration of $22.6 \pm 0.5$ pg MTX cell ${ }^{-1}$. Maitotoxin- 4 was found in all seven G. excentricus strains examined (13-72.8 pg MTX eq cell $^{-1}$ ), independently of their geographical origin (Table 4).

MRM transitions of bi-charged anions $(1637.5,1648.2,1656.0 \mathrm{~m} / \mathrm{z})$ of MTX2 towards the $\left[\mathrm{HOSO}_{3}\right]^{-}$ $(96.9 \mathrm{~m} / z)$ were not found in any of the strains examined. Putative MTX2 identified using 1091.5 and/or 1103.8 tri-charged anions as parent ions was found in G. caribaeus, G. excentricus, G. pacificus and Gambierdiscus sp. Viet Nam. HRMS analyses conducted on the most concentrated samples (G. excentricus strains, G. pacificus G10-DC and Gambierdiscus sp. Viet Nam) unveiled that peaks found in LRMS/MS for MTX2 were actually false positives: 1091.5 was indeed a mono-charged ion species, so it could not be the molecular tri-charged anion $[\mathrm{M}-3 \mathrm{H}]^{3-}$ estimated for MTX2. HRMS analyses also revealed very similar RT and MS/MS spectra for the peak with a nominal mass of 1091.5 in the two strains G. pacificus G10-DC and Gambierdiscus sp. Viet Nam, even though they had a different accurate mass. Additionally, the compound with a similar nominal mass of 1091.5 had a different $R T$ and HRMS/MS fragmentation pathway in the G. excentricus strain Pulley Ridge Gam2 (Figure 7).

Putative MTX3 analogs were found in all Fukuyoa and Gambierdiscus strains examined. LRMS/MS already suggested at least two different compounds with $m / z=1037.6$, i.e., one compound present in all G. excentricus strains $(R T=4.0-4.1 \mathrm{~min})$ and one in some strains of other species $(R T=4.8-4.9 \mathrm{~min})$ (Table 4). HRMS analyses confirmed the differences between G. excentricus strains and all the other strains (G. australes VGO1178, CCMP1653 and S080911_1; G. balechii VGO917 and VGO920; G. caribaeus CCMP1733 and Bill Hi Gam8; G. carpenteri GT4 and WHBR21; G. pacificus CCMP1650; G. scabrosus KW070922_1) (Figure 8).

For G. excentricus species, LH-20 fractionation of VGO791 and VGO792 showed no correlation between the cytotoxicity observed and the peak intensities corresponding to p-MTX2 $\left(V_{\mathrm{e}}=21.0-34.0 \mathrm{~mL}\right)$ and p-MTX3 $\left(V_{\mathrm{e}}=16.0-29.0 \mathrm{~mL}\right)$ analogs but only with MTX4 (Section 2.6). 


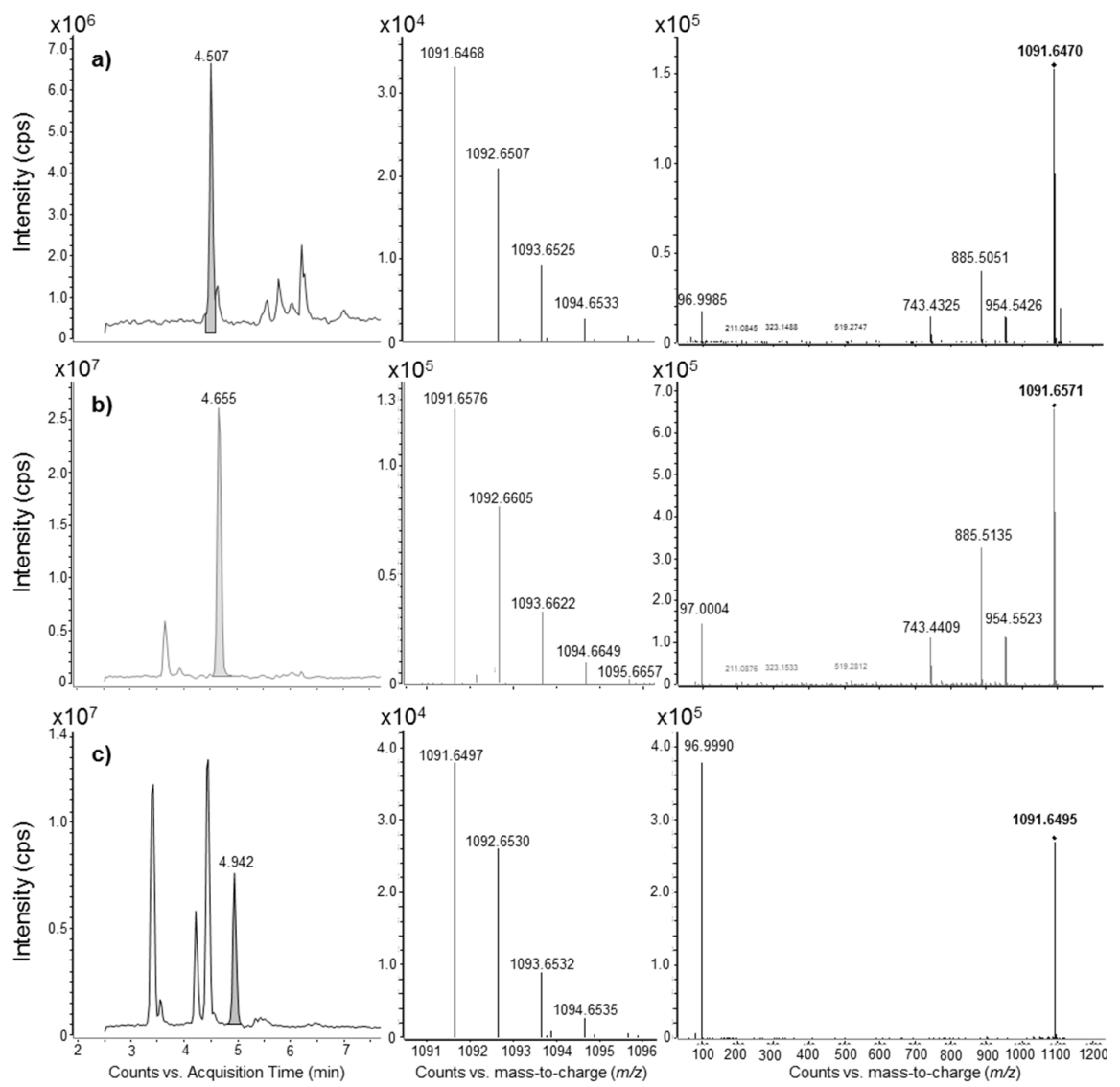

Figure 7. False positives for MTX2. Negative electrospray chromatogram, HRMS spectra and averaged HRMS/MS spectra (CEs = 25, 50 and $75 \mathrm{eV}$ ) of $1091.5 \mathrm{~m} / \mathrm{z}$ found in crude extracts of: (a) G. pacificus G10-DC, (b) Gambierdiscus sp. Viet Nam and (c) G. excentricus Pulley Ridge Gam2.

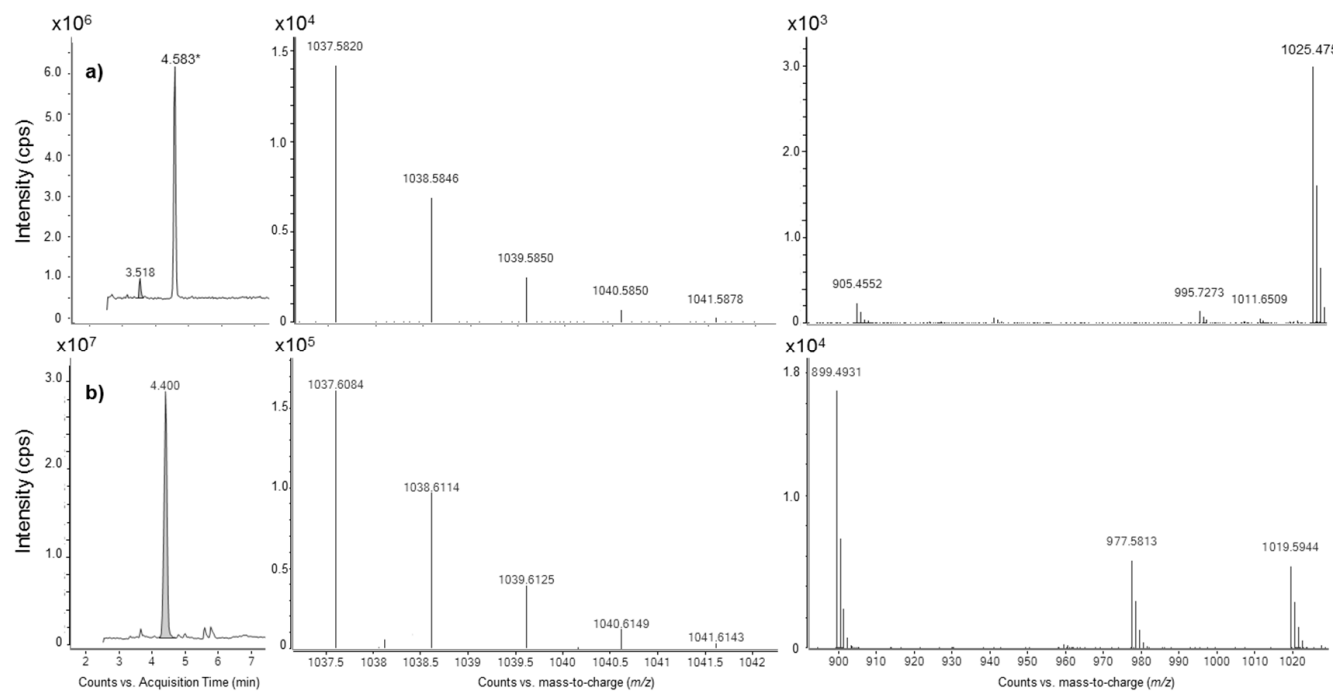

Figure 8. Putative candidates for MTX3. Negative electrospray chromatogram, HRMS spectra and averaged HRMS/MS spectra (CEs = 50, 100 and $150 \mathrm{eV}$ ) of $1037.5 \mathrm{~m} / \mathrm{z}$ found in crude extracts of (a) G. excentricus VGO792, used as example for all G. excentricus strains; (b) G. australes S080911_1, used as example for all G. australes, G. balechii, G. caribaeus, G. carpenteri, G. pacificus, G. scabrosus strains. HRMS/MS spectra are presented with a zoom on an $m / z$ range from 900 to 1020 . * = peak only observed due to large mass window in quadrupole filter of HRMS/MS. 
Table 4. Screening for the presence of MTX analogs in crude extracts of a total of 44 strains of Gambierdiscus and Fukuyoa using LC-LRMS/MS analysis. MTX4 content is expressed in pg MTX eq cell ${ }^{-1}$, assuming an equimolar response of MTX4 and MTX in MS. RT: retention time. ND: not detected. *: only one replicate available. LOD for MTX and MTX4 per sample is indicated in parenthesis and it is expressed in pg MTX eq cell ${ }^{-1}$. LODs were calculated according to the number of cells extracted for each strain (Table 5)

\begin{tabular}{|c|c|c|c|c|c|c|c|}
\hline \multirow[b]{2}{*}{ Species } & \multirow[b]{2}{*}{ Strain } & \multirow{2}{*}{$\begin{array}{c}\text { MTX } \\
\text { pg MTX cell }{ }^{-1} \\
\pm \text { SD }(n=3) \\
R T=4.64 \mathrm{~min}\end{array}$} & \multicolumn{2}{|c|}{ p-MTX2 } & \multicolumn{2}{|c|}{ p-MTX3 } & \multirow{2}{*}{$\begin{array}{c}\text { MTX4 } \\
\text { pg MTX eq cell } \\
\pm \text { SD }(n=3) \\
R T=5.05 \mathrm{~min}\end{array}$} \\
\hline & & & $1091.5 \rightarrow 96.9$ & $1103.8 \rightarrow 96.9$ & $1015.5 \rightarrow 96.9$ & $1037.6 \rightarrow 96.9$ & \\
\hline \multirow{2}{*}{ F. ruetzleri } & Gam1 & $\mathrm{ND}(<2.97)$ & ND & ND & ND & $R T=4.89 \& 5.74$ & $\mathrm{ND}(<2.97)$ \\
\hline & WH55-Gam4 & $\mathrm{ND}(<4.97)$ & ND & ND & ND & $R T=4.88$ & $\mathrm{ND}(<4.97)$ \\
\hline \multirow{4}{*}{ G. australes } & CCMP1653 (NOAA 24) (T39) & $\mathrm{ND}(<1.54)$ & ND & ND & ND & $R T=4.86$ & $\mathrm{ND}(<1.54)$ \\
\hline & S080911_1 & $22.6 \pm 0.5$ & ND & ND & ND & $R T=4.86$ & $\mathrm{ND}(<0.80)$ \\
\hline & VGO1178 & $\mathrm{ND}(<2.46)$ & ND & ND & ND & $R T=4.87$ & $\mathrm{ND}(<2.46)$ \\
\hline & VGO1181 & $\mathrm{ND}(<2.22)$ & ND & ND & ND & $R T=4.87$ & $\mathrm{ND}(<2.22)$ \\
\hline \multirow{2}{*}{ G. balechii } & VGO917 & $\mathrm{ND}(<1.66)$ & ND & ND & $R T=4.10 \& 4.21$ & $R T=4.80$ & $\mathrm{ND}(<1.66)$ \\
\hline & VGO920 & $\mathrm{ND}(<2.02)$ & ND & ND & $R T=3.94$ & $R T=4.86$ & $\mathrm{ND}(<2.02)$ \\
\hline \multirow{3}{*}{ G. belizeanus } & CCMP399 (NOAA2) (SB03) & $\mathrm{ND}(<3.51)$ & ND & ND & ND & $R T=4.80$ & $\mathrm{ND}(<3.51)$ \\
\hline & Keys Gam1 & $\mathrm{ND}(<7.79)$ & ND & ND & ND & $R T=4.80$ & $\mathrm{ND}(<7.79)$ \\
\hline & ST1-F4 & $\mathrm{ND}(<6.20)$ & ND & ND & ND & $R T=4.83$ & ND $(<6.20)$ \\
\hline \multirow{5}{*}{ G. caribaeus } & CCMP1733 (NOAA11) & $\mathrm{ND}(<2.27)$ & $R T=3.64 \& 4.28$ & $R T=3.64 \& 4.28$ & ND & $R T=4.84$ & $\mathrm{ND}(<2.27)$ \\
\hline & Bill Hi Gam8 & $\mathrm{ND}(<5.79)$ & $R T=4.05 \& 4.30$ & $R T=4.05 \& 4.30$ & ND & $R T=4.83$ & $\mathrm{ND}(<5.79)$ \\
\hline & CCMP1651 (NOAA20) & $\mathrm{ND}(<10.27)$ & $R T=4.27$ & $R T=4.27$ & ND & $R T=4.82$ & $\mathrm{ND}(<10.27)$ \\
\hline & Dive $1 \mathrm{fa}$ Gam1 & $\mathrm{ND}(<1.69)$ & $R T=4.26$ & $R T=4.26$ & ND & $R T=4.83$ & $\mathrm{ND}(<1.69)$ \\
\hline & Mexico Algae1 Gam1 & $\mathrm{ND}(<5.19)$ & $R T=4.27$ & $R T=4.27$ & ND & $R T=4.80$ & $\mathrm{ND}(<5.19)$ \\
\hline \multirow{3}{*}{ G. carolinianus } & ETB Exp28 Gam10 & $\mathrm{ND}(<10.49)$ & ND & ND & $R T=4.55,6.11 \& 6.21$ & $R T=4.89,6.11 \& 6.21$ & $\mathrm{ND}(<10.49)$ \\
\hline & Greece Gam2 & $\mathrm{ND}(<7.73)$ & ND & ND & $R T=4.54 \& 6.21$ & $R T=4.86,6.21 \& 7.17$ & $\mathrm{ND}(<7.73)$ \\
\hline & RROV5 & $\mathrm{ND}(<5.47)$ & ND & ND & $R T=5.12 \& 6.25$ & $R T=5.12 \& 6.25$ & $\mathrm{ND}(<5.47)$ \\
\hline \multirow{4}{*}{ G. carpenteri } & GT4 & $\mathrm{ND}(<7.27)$ & ND & ND & ND & $R T=4.86$ & $\mathrm{ND}(<7.27)$ \\
\hline & Jamaica Algae2 Gam1 & $\mathrm{ND}(<6.51)$ & ND & ND & ND & $R T=4.81$ & $\mathrm{ND}(<6.51)$ \\
\hline & Pat Hi Jar7 Gam11 & $\mathrm{ND}(<10.72)$ & ND & ND & ND & $R T=4.86$ & $\mathrm{ND}(<10.72)$ \\
\hline & WHBR21 & $\mathrm{ND}(<6.62)$ & ND & ND & ND & $R T=4.84$ & $\mathrm{ND}(<6.62)$ \\
\hline \multirow{7}{*}{ G. excentricus } & Pulley Ridge Gam 2 & $\mathrm{ND}(<0.39)$ & $R T=5.68$ & ND & ND & $R T=4.01$ & $22.9 *$ \\
\hline & UNR-07 & $\mathrm{ND}(<0.63)$ & $R T=5.64$ & ND & ND & $R T=4.05$ & $16.0 \pm 2.3$ \\
\hline & UNR-08 & $\mathrm{ND}(<1.45)$ & $R T=5.68$ & ND & ND & $R T=4.05$ & $19.8 \pm 6.4$ \\
\hline & VGO1035 & $\mathrm{ND}(<2.64)$ & $R T=5.68$ & ND & ND & $R T=4.01$ & $13.0 *$ \\
\hline & VGO790 & $\mathrm{ND}(<3.73)$ & $R T=5.67$ & ND & ND & $R T=4.01$ & $23.2 *$ \\
\hline & VGO791 & $\mathrm{ND}(<0.29)$ & $R T=5.67$ & ND & ND & $R T=3.71 \& 4.01$ & $72.8 \pm 8.5$ \\
\hline & VGO792 & $\mathrm{ND}(<0.30)$ & $R T=5.68$ & ND & ND & $R T=3.68 \& 3.99$ & $20.0 \pm 2.9$ \\
\hline
\end{tabular}


Table 4. Cont

\begin{tabular}{|c|c|c|c|c|c|c|c|}
\hline \multirow[b]{2}{*}{ Species } & \multirow[b]{2}{*}{ Strain } & \multirow{2}{*}{$\begin{array}{c}\text { MTX } \\
\text { pg MTX cell }{ }^{-1} \\
\pm \text { SD }(n=3) \\
R T=4.64 \mathrm{~min} \\
\end{array}$} & \multicolumn{2}{|c|}{ p-MTX2 } & \multicolumn{2}{|c|}{ p-MTX3 } & \multirow{2}{*}{$\begin{array}{c}\text { MTX4 } \\
\text { pg MTX eq cell-1 } \\
\pm \text { SD }(n=3) \\
R T=5.05 \mathrm{~min}\end{array}$} \\
\hline & & & $1091.5 \rightarrow 96.9$ & $1103.8 \rightarrow 96.9$ & $1015.5 \rightarrow 96.9$ & $1037.6 \rightarrow 96.9$ & \\
\hline \multirow[t]{2}{*}{ G. pacificus } & CCMP1650 (NOAA 9) (MR1) & $\mathrm{ND}(<1.02)$ & $\begin{array}{c}R T=5.33,6.06, \\
\quad 6.24 \& 6.82\end{array}$ & $\begin{array}{c}R T=5.33,6.06, \\
\quad 6.24 \& 6.82\end{array}$ & ND & $R T=4.89$ & $\mathrm{ND}(<1.02)$ \\
\hline & G10DC & $\mathrm{ND}(<0.66)$ & $R T=5.06$ & ND & $R T=3.90 \& 4.15$ & - & $\mathrm{ND}(<0.66)$ \\
\hline \multirow{4}{*}{$\begin{array}{l}\text { Gambierdiscus sp. } \\
\text { ribotype } 2\end{array}$} & CCMP1655 (MQ2) & $\mathrm{ND}(<5.87)$ & ND & ND & ND & $R T=4.83$ & $\mathrm{ND}(<5.87)$ \\
\hline & Mixed PR & $\mathrm{ND}(<6.49)$ & ND & ND & ND & $R T=4.90$ & $\mathrm{ND}(<6.49)$ \\
\hline & St Maartens Gam10 & $\mathrm{ND}(<5.52)$ & ND & ND & ND & $R T=4.90$ & $\mathrm{ND}(<5.52)$ \\
\hline & SW Algae Gam1 & $\mathrm{ND}(<8.38)$ & ND & ND & ND & $R T=4.81$ & $\mathrm{ND}(<8.38)$ \\
\hline G. scabrosus & KW070922_1 & $\mathrm{ND}(<0.83)$ & ND & ND & ND & $R T=4.80$ & $\mathrm{ND}(<0.83)$ \\
\hline \multirow{3}{*}{ G. silvae } & UNR-30 & $\mathrm{ND}(<1.76)$ & ND & ND & $R T=5.93 \& 6.13$ & $\begin{array}{c}R T=3.22,4.76,5.35 \\
5.93,6.13,6.98\end{array}$ & $\mathrm{ND}(<1.76)$ \\
\hline & VGO1167 & $\mathrm{ND}(<1.27)$ & ND & ND & - & $R T=4.83$ & $\mathrm{ND}(<1.27)$ \\
\hline & VGO1180 & ND $(<1.52)$ & ND & ND & $R T=5.92 \& 6.14$ & $R T=4.68,5.92 \& 6.14$ & ND $(<1.52)$ \\
\hline Gambierdiscus sp. & Viet Nam & $\mathrm{ND}(<0.37)$ & $R T=5.14$ & ND & $R T=7.02$ & $R T=7.64$ & $\mathrm{ND}(<0.37)$ \\
\hline \multirow{3}{*}{ G. toxicus } & GTT-91 & $\mathrm{ND}(<5.49)$ & ND & ND & $R T=2.94$ & $R T=4.89$ & $\mathrm{ND}(<5.49)$ \\
\hline & HIT-0 & $\mathrm{ND}(<6.00)$ & ND & ND & $R T=2.92$ & $R T=4.89$ & $\mathrm{ND}(<6.00)$ \\
\hline & HIT-25 & $\mathrm{ND}(<8.56)$ & ND & ND & $R T=2.90$ & $R T=4.88$ & $\mathrm{ND}(<8.56)$ \\
\hline
\end{tabular}




\section{Discussion}

\subsection{Gambierdiscus excentricus and the Discovery of Maitotoxin-4}

Recent studies showed G. excentricus as one of the most toxic species known to date, both for CTXs and MTXs $[61,69,75]$. The species was first described in the Canary Islands [61], a subtropical region (North-Eastern Atlantic Ocean) from which Ciguatera Fish Poisoning (CFP) has recently been reported [76,77]. Subsequently, it has also been found in Brazil [78,79] and in the Caribbean Sea [75]. The aim of the present study was to identify maitotoxin or analogs produced by this species using high resolution mass spectrometry (HRMS).

Several difficulties had to be surmounted in the present study to identify such analogs. While the N2a cytotoxicity assay allowed for MTX detection at $\mathrm{ng} \mathrm{mL}^{-1}$ levels, comparable to what had been reported by Caillaud, et al. [80], Q-Tof LC-HRMS (negative ion acquisition mode) had dramatically poorer sensitivity, with an LOD for MTX at $1.88 \mu \mathrm{g} \mathrm{mL}^{-1}$. The LOD of MTX using HRMS was relatively high compared to the LOD reported for LRMS [3]. However, as MTX itself was not present, an untargeted approach based on full-scan HRMS was necessary to screen for any potential analogs present, and the lower sensitivity of this technique had to be accepted. Compared to the need for $\mu \mathrm{g}$ quantities of toxin for LC-HRMS analysis, maitotoxic species only produce up to ca. $80 \mathrm{pg}$ MTX eq cell $^{-1}$ [69]. Hence, it was necessary to have a substantial biomass for purification purposes in order to obtain detectable amounts of toxin. Gambierdiscus excentricus is difficult to cultivate compared to other algae, including other Gambierdiscus species [69,75]. This is challenging because Gambierdiscus species grow extremely slowly $\left(0.08-0.10\right.$ divisions day $\left.{ }^{-1}\right)$ compared to most other microalgae $[69,75,81,82]$. Hence, large-scale cultures of the Canary Island strains VGO791 and VGO792 were necessary to obtain sufficient material (>2 million cells) for LC-HRMS analysis.

Once sufficient biomass was obtained, toxicity screening (N2a-based assays) was applied to identify toxic fractions following liquid-liquid partitioning and LH-20 chromatography. Results of both N2a cytotoxicity and $\mathrm{Ca}^{2+}$ flux assays on LH-20 fractions suggested that G. excentricus strains produce compound(s) with relatively high molecular weight (early elution on LH-20) and $\mathrm{Ca}^{2+}$-related activity (N2a assays), similar to MTX. Chemical analyses using LC-HRMS (full scan mode) and LC-HRMS/MS (targeted mode) led to the discovery of a novel MTX analog, named maitotoxin-4 (MTX4), a sulfated compound with an accurate mono-isotopic mass of $3292.4860 \mathrm{Da}$ (for the free acid form). No MTX2 was detected in any of the seven strains of G. excentricus, and, additionally, toxicity in LH-20 fractions was not correlated to putative MTX3. Therefore, and even though MTX4 was not yet completely purified, the correlation between MTX4 content in pre-purified fractions and their N2a cytotoxicity (Figure 6) supports the hypothesis that MTX4 is a major contributor to the toxicity of the MSF fraction of G. excentricus.

MTX equivalents measured in LH-20 fractions of both strains of G. excentricus, using the N2a cytotoxicity assay (Section 2.6), were 3.5-fold higher than the MTX4 content measured via LC-LRMS/MS for an equivalent number of extracted cells. This factor of 3.5 does not necessarily indicate that the toxin content is overestimated using the cytotoxicity assay as the following assumptions were made: (i) MTX4 exhibits the same toxicity as MTX and (ii) MTX and MTX4 have the same behavior in MS, i.e., that they have an equimolar response. The relative toxicity between the two molecules is not yet known, and neither are their ionization and fragmentation yields known in MS. Furthermore, as suggested by Lewis et al. [57] for several other Gambierdiscus species, additional analogs of MTX4 may be present in the same LH-20 fractions, albeit at lower concentration as we were not able to identify such analogs by HRMS.

\subsection{Screening for the Presence of Other MTX Analogs}

Another aim of the present study was to assess the diversity of previously reported MTX analogs produced by different strains and species of the genera Gambierdiscus and Fukuyoa. In order to achieve this goal, an LC-LRMS/MS method (API 4000 QTrap) was developed to screen for the presence of four MTX analogs in the extracts of two strains of $F$. ruetzleri and 42 strains representing 11 species, one 
ribotype and one strain of undetermined species (Gambierdiscus sp. Viet Nam) of Gambierdiscus spp. (Section 4.6.2).

Previous LC-LRMS/MS studies conducted by a group from the Cawthron Institute $[59,64,66,71-74]$ evaluated the presence of MTX and putative MTX3 in a total of 32 strains of Gambierdiscus and Fukuyoa, i.e., two strains of $F$. cf. yasumotoi, 13 strains of G. australes, one strain of G. belizeanus, one strain of G. carpenteri, two strains of G. cheloniae, two strains of G. honu, six strains of G. lapillus, four strains of G. pacificus and one strain of G. polynesiensis. These authors reported that MTX was only present in 11 out of 13 G. australes strains (0.3-36.6 pg MTX cell ${ }^{-1}$ ), one originating from Cook Islands [71] and the other ten from Kermadec Islands [74]. In our present study, MTX was only detected in the one strain of G. australes (S080911_1) from Japan, at a concentration of $22.6 \mathrm{pg}$ MTX cell $^{-1}$, also confirmed by LC-HRMS. The other three strains of G. australes examined in this study (CCMP1653, from Hawaii; VGO1178 and VGO1181, from Canary Islands) did not contain detectable (>LOD) levels of MTX. This absence of MTX in the other strains may derive from comparatively high LODs around 1/10th of the concentration of MTX detected in the G. australes strain from Japan. Still, this finding is consistent with previous studies in suggesting that MTX itself has been mostly confirmed in strains of G. australes, at least since the most recent taxonomic separation into species and phylotypes. Again, chemical diversity in G. australes may also be larger than reported until now since Lewis et al. [57] reported at least two compounds with $\mathrm{Ca}^{2+}$ flux activity in a strain of G. australes.

Maitotoxin-4 was produced by all strains of G. excentricus examined in this study (13.0-72.8 pg MTX eq cell ${ }^{-1}$ ) (Table 4), independently of their geographical origin, albeit all seven from the Atlantic Ocean (Brazil, Canary Islands and Caribbean Sea), and was not detected in any other species examined. These findings suggest that the production of certain MTX analogs is likely to be species-specific within Gambierdiscus and Fukuyoa genera.

While results were clear and consistent with previous studies for MTX and MTX4, further examination is needed concerning MTX2 and MTX3. Maitotoxin-2 was described only once, in 1990, from an Australian strain of Gambierdiscus sp. (NQ1) by Holmes et al. [55]. To our knowledge, no LC-MS/MS method has been described for the detection of MTX2, set aside one study by Lewis et al. [56], which reported negative ionspray MS data based on infusion (using an orifice voltage of $-120 \mathrm{~V})$ of MTX2 dissolved in $\mathrm{MeOH}: \mathrm{H}_{2} \mathrm{O}(1: 1, v / v)$. The assigned negative ion species for the most intense MS peaks were: $1648.2 \mathrm{~m} / z$ for $[\mathrm{M}+\mathrm{Na}-3 \mathrm{H}]^{2-}, 1656.0 \mathrm{~m} / z$ for $[\mathrm{M}+\mathrm{K}-3 \mathrm{H}]^{2-}$, $1098.6 \mathrm{~m} / z$ for $[\mathrm{M}+\mathrm{Na}-4 \mathrm{H}]^{3-}$ and $1103.8 \mathrm{~m} / z$ for $[\mathrm{M}+\mathrm{K}-4 \mathrm{H}]^{3-}$. MTX2 is assumed to be a mono-sulfated compound [53,56]. In the absence of MS fragmentation data for maitotoxin-2 (MTX2), the MRM transitions chosen in this study were based on bi-charged and tri-charged molecular anions and their respective sodium and potassium adducts pointing towards the hydrogenated sulfate anion $\left[\mathrm{HOSO}_{3}\right]^{-}$. Therefore, analysis additionally included $1091.5 \mathrm{~m} / \mathrm{z}$ for $[\mathrm{M}-3 \mathrm{H}]^{3-}$ and $1637.5 \mathrm{~m} / \mathrm{z}$ for $[\mathrm{M}-2 \mathrm{H}]^{2-}$, derived from analogy with spectral behavior observed for MTX and MTX4. None of the strains presented a chromatographic peak with both bi- and tri-charged anion clusters in the mass spectrum. All strains of several species (G. caribaeus, G. excentricus, G. pacificus and Gambierdiscus sp. Viet Nam) were positive for the anion cluster of the nominal mass 1091.5 (which could potentially correspond to $[\mathrm{M}-3 \mathrm{H}]^{3-}$ of MTX2). HRMS unveiled that these compounds were false positives of MTX2: the parent ion 1091.5 is actually a mono-charged ion species in G. excentricus strains, G. pacificus G10-DC and Gambierdiscus sp. Viet Nam (not sufficient sample material for G. caribaeus). Therefore, low resolution MS may misidentify these compounds for MTX2 in several species. Moreover, different retention time, accurate mass and HRMS/MS fragmentation pattern also revealed that the sulfated compound with an $m / z 1091.5$ found in G. excentricus strains was different from those found in G. pacificus G10-DC and Gambierdiscus sp. Viet Nam (Figure 7).

Maitotoxin-3 was isolated in 1994 from an Australian strain of Gambierdiscus sp. (WC1/1) by Holmes, et al. [53]. The only existing MS data are from positive ionspray MS analysis at different orifice potentials [56]. The authors described MTX3 as a disulfated compound (MW = 1060.5 Da for the disodium salt), with the most intense MS peak at $1039.5 \mathrm{~m} / \mathrm{z}$ for the mono-sodiated adduct $[\mathrm{M}+$ $\mathrm{Na}]^{+}$[56]. The only existing LC-LRMS/MS method for MTX3 detection has been developed by Kohli 
at the Cawthron Institute (Nelson, New Zealand) in 2013 and uses negative ionization mode [72]. This method identified a putative MTX3 (p-MTX3) based on the MRM transition $m / z 1037.6 \rightarrow 96.8$. The parent ion at $1037.6 \mathrm{~m} / \mathrm{z}$ had been incorrectly assigned to [M $-\mathrm{H}]^{-}$by Kohli [72]; indeed, according to the original study [56], it actually corresponds to $[\mathrm{M}+\mathrm{Na}-2 \mathrm{H}]^{-}$. All but one (G. carpenteri Merimbula) out of the 32 strains examined by the group of the Cawthron Institute were positive for the presence of p-MTX3 $[59,64,66,71-74]$. All the strains examined in this present study were also positive for the presence of p-MTX3, suggesting that p-MTX3 is ubiquitous within Gambierdiscus and Fukuyoa genera. Interestingly, the parent ion chosen for p-MTX3 $\left([\mathrm{M}+\mathrm{Na}-2 \mathrm{H}]^{-}\right)$has the same nominal $\mathrm{m} / \mathrm{z}$ as that for 2,3-dihydroxyCTX3C in negative ionization MS after loss of one molecule of water $\left(\mathrm{m} / z 1037.5\right.$ for $\left[\mathrm{M}-\mathrm{H}-\mathrm{H}_{2} \mathrm{O}^{-}\right)$. 2,3-dihydroxyCTX3C is considered to be an oxidation product of CTX3C and has extensively been found in Gambierdiscus [80,83]. In one study, conducted by Roeder et al. [83], however, it had been the only analog present in ten out of a total of eleven Gambierdiscus strains, and this study also used low resolution negative ionization MS. It is surprising that CTX3C had not been detected in that study along with 2,3-dihydroxyCTX3C, except for one strain (Gambierdiscus sp. Viet Nam). Therefore, we presume that this study by Roeder et al. [83] may have misidentified 2,3-dihydroxyCTX3C, as it is likely that the actual compound present was the ubiquitous p-MTX3. Therefore, we recommend that when attempting to detect 2,3-dihydroxyCTX3C in negative mode LRMS/MS to verify that the compound does not have a loss of sulfate since this points towards p-MTX3 rather than 2,3-dihydroxyCTX3C. In our study, the tentative identification of p-MTX3 involved different possible parent ions (in some cases 1037.6, on other occasions 1015.5, and sometimes both) with different retention times, therefore different compounds were present that could be tentatively related to MTX3. HRMS/MS analyses for the most concentrated samples confirmed presence of sulfate ester group(s) in these compounds which is coherent with these compounds responding to the transition of the sulfate loss in low resolution tandem MS. At least one of the compounds, i.e., the one identified in all G. excentricus strains, does not correlate with cytotoxicity which suggests that this potential MTX analog is not important in accounting for toxicity.

It should also be noted that Gambierdiscus species produce other polyether compounds besides MTX containing sulfate ester group(s). Consequently, the presence of sulfate ester group(s) alone does not constitute definitive evidence for the presence of MTX. For example, a recent study conducted by Rodríguez, et al. [84] reported on the isolation and structural characterization (HRMS and NMR) of gambierone $\left(\mathrm{C}_{51} \mathrm{H}_{76} \mathrm{O}_{19} \mathrm{~S}\right.$, with an exact mass of $\left.1024.47015 \mathrm{Da}\right)$ from G. belizeanus CCMP401. This molecule is a ladder-shaped polyether toxin and presents a sulfate ester group, but, contrarily to MTX, it behaves as a sodium channel activator such as CTXs, albeit with significantly smaller activity. Similarly, Watanabe, et al. [85] reported on the structural elucidation (HRMS and NMR) of gambieroxide $\left(\mathrm{C}_{60} \mathrm{H}_{90} \mathrm{O}_{22} \mathrm{~S}\right.$, with an exact mass of 1194.5644), another sulfate-containing polyether compound isolated from G. toxicus GTP-2 (French Polynesia). Its chemical structure is very similar to that of yessotoxin (YTX); its biological activity has not yet been described.

Care should be taken in compound identification when operating in low-resolution mass spectrometry, especially when the standard is not commercially available and when searching for non-specific MRM transitions. In the present study, purification of MTX4 has not been completed and it was not possible to elucidate the full structure due to compound scarcity. Still, the evidence presented here for MTX4 as a MTX analog is based on (i) ion cluster similarity of MTX4 with MTX, (ii) targeted HRMS (loss of sulfate), (iii) bioguided fractionation behavior (both partitioning and size-exclusion chromatography), and (iv) the high cytotoxicity and $\mathrm{Ca}^{2+}$ influx activity. These data taken together strongly suggest that the novel molecule is a MTX analog. As MTX4 is a compound correlated with high cytotoxicity and could serve as a biomarker for the highly toxic G. excentricus species in the Atlantic area, further studies will focus on HRMS specific fragmentation pathways of MTX and MTX4, in both positive and negative ionization modes, and eventually nuclear magnetic resonance once sufficient compound is available. 


\section{Materials and Methods}

\subsection{Reference Toxins and Chemicals}

Maitotoxin (MTX) was purchased from Wako Chemicals USA, Inc. (Richmond, VA, USA) and was used as the reference standard for cellular bioassays and chemical analyses. MTX was dissolved and stored in $\mathrm{MeOH}: \mathrm{H}_{2} \mathrm{O}(1: 1, v / v)$. The stock solution was prepared at a concentration of $20 \mu \mathrm{g} \mathrm{mL}^{-1}$.

HPLC grade methanol and dichloromethane for extraction were purchased from Sigma Aldrich (Saint Quentin Fallavier, France). Milli-Q water was supplied by a Milli-Q integral 3 system (Millipore, Saint-Quentin-Yvelines, France). Water (Optima quality), acetonitrile (Optima quality), formic acid (Puriss quality) and ammonium formate (Purity for MS) were used to prepare mobile phases. These chemicals were purchased from Sigma Aldrich (Saint Quentin Fallavier, France).

Eagle's Minimum Essential Medium (EMEM, ATCC ${ }^{\circledR}$ 30-2003) for culture of mouse neuroblastoma neuro-2a (N2a) cells at the Phycotoxins Laboratory was purchased from the American Type Culture Collection (ATCC). Roswell Park Memorial Institute 1640 medium supplemented with glutamine (RPMI-1640-GlutaMAX ${ }^{\mathrm{TM}}$ ) for culture of N2a cells at the ANSES Laboratory was purchased from Thermofisher Scientific (Waltham, MA, USA). The following additives to the N2a medium were purchased from Sigma Aldrich (Saint Quentin Fallavier, France): sodium pyruvate, streptomycin, penicillin and fetal bovine serum (Phycotoxins Laboratory) or fetal calf serum (ANSES Laboratory). N2a assay reagents were also purchased from Sigma Aldrich (Saint Quentin Fallavier, France): trypsin-(ethylenediaminetetraacetic acid) (trypsin-EDTA) and 3-(4,5-dimethylthiazol-2-yl)-2,5-diphenyl tetrazolium bromide (MTT). Fluo-4-AM and Hoechst 33342 probes for the $\mathrm{N} 2 \mathrm{a} \mathrm{Ca}^{2+}$ flux high-content screening (HCS) assay were purchased from Thermofisher Scientific (Waltham, MA, USA).

\subsection{Gambierdiscus and Fukuyoa Strains Examined in This Study}

The 44 strains of Gambierdiscus and Fukuyoa, which were examined in this study, and their location of origin, culture conditions and number of cells extracted are listed in Table 5. Strains were cultivated either at the Phycotoxins Laboratory (PHYC, Ifremer, Nantes, France) [69], or at the Center for Coastal Fisheries Habit Research Laboratory (CCFHR, NOAA, Beaufort, NC, USA) [75], or at the University of Rio (UNIRIO, Federal University of Rio de Janeiro State, RJ, Brazil) [79].

\subsection{Cell Pellet Extraction}

Cell pellets of Gambierdiscus and Fukuyoa strains were extracted three times with $\mathrm{MeOH}(30 \mathrm{~mL}$ per 1 million cells) using a $3 \mathrm{~mm}$ diameter probe sonicator (Q-Sonica, Q700, Newtown, CT, USA) at $30 \%$ of the total power $(500 \mathrm{~W})$. The sonication was conducted in an ice bath $\left(0{ }^{\circ} \mathrm{C}\right)$ for $15 \mathrm{~min}$ in pulse mode ( $10 \mathrm{~s} \mathrm{ON}, 5 \mathrm{~s}$ OFF). At the end of each sonication step, the supernatant (crude extract) was collected by centrifugation $\left(4^{\circ} \mathrm{C}, 10 \mathrm{~min}, 4000 \mathrm{~g}\right)$. Crude extracts were filtered through a Nanosep MF $0.2 \mu \mathrm{m}$ filter and stored at $-20^{\circ} \mathrm{C}$ until LC-MS analyses. 
Table 5. List of the two Fukuyoa and 42 Gambierdiscus strains examined in this study along with their species designation, geographical origin, culture collection of origin, culture conditions, number of cells extracted for toxin analysis and the references where the strains have been previously cited. CCFHR: National Oceanographic and Atmospheric Administration (NOAA), National Ocean Service, National Centers for Coastal Ocean Science, Center for Coastal Fisheries Habit Research (CCFHR), Beaufort, NC, USA; CCVIEO: Culture Collection of Harmful Microalgae of IEO (CCVIEO), Centro de Vigo, Vigo, Spain; IRTA: Investigación y tecnología agroalimentarias,

Department of Agriculture, Government of Catalonia, Sant Carles de la Ràpita, Spain; KU: Kochi University (KU), Kochi, Japan; NCMA: Provasoli-Guillard National Center for Marine Algae and Microbiota (NCMA), Bigelow Laboratory for Ocean Sciences, East Boothbay, Maine, USA; UNIRIO: Rio de Janeiro State, Federal University (UNIRIO), Rio de Janeiro, RJ, Brazil; VNIO: Viet Nam National Institute of Oceanography (VNIO, VAST), Vinh Nguyen, Nha Trang, Viet Nam.

\begin{tabular}{|c|c|c|c|c|c|c|}
\hline Species/Phylotype & Strain & Geographical Origin & $\begin{array}{l}\text { Culture } \\
\text { Collection }\end{array}$ & $\begin{array}{l}\text { Culture } \\
\text { Conditions }\end{array}$ & $\begin{array}{c}\text { Number of } \\
\text { Cells Extracted }\end{array}$ & Reference \\
\hline \multirow{2}{*}{ F. ruetzleri } & Gam1 & Southwater Cay, Belize & CCFHR & CCFHR & 215,190 & {$[57,68]$} \\
\hline & WH55-Gam4 & $\begin{array}{l}\text { Flower Garden Banks National Marine Sanctuary (West Bank), } \\
\text { Northwestern Gulf of Mexico, United States of America }\end{array}$ & CCFHR & CCFHR & 128,800 & [75] \\
\hline \multirow{4}{*}{ G. australes } & CCMP1653 (NOAA 24) (T39) & Tern Island, Hawaii, United States of America & NCMA & PHYC & 416,220 & {$[58,86]$} \\
\hline & S080911_1 & Kutsu, Susaki, Kochi, Japan & KU & PHYC & 798,285 & [87] \\
\hline & VGO1178 & Punta Hidalgo, Tenerife, Canary Islands, Spain & CCVIEO & PHYC & 260,388 & {$[62,69]$} \\
\hline & VGO1181 & Punta Hidalgo, Tenerife, Canary Islands, Spain & CCVIEO & PHYC & 288,608 & {$[69]$} \\
\hline \multirow[b]{2}{*}{ G. balechii } & VGO917 & Manado, Celebes Sea, Indonesia & CCVIEO & PHYC & 384,650 & {$[60,88]$} \\
\hline & VGO920 & Manado, Celebes Sea, Indonesia & CCVIEO & PHYC & 317,600 & {$[60]$} \\
\hline \multirow{3}{*}{ G. belizeanus } & CCMP399 (NOAA2) (SB03) & $\begin{array}{l}\text { St. Barthélemy Island, Caribbean, Territorial collectivity of } \\
\text { Saint-Barthélemy }\end{array}$ & NCMA & PHYC & 182,495 & {$[57,58]$} \\
\hline & Keys Gam1 & Florida Keys, Florida, United States of America & CCFHR & CCFHR & 82,125 & [68] \\
\hline & ST1-F4 & St. Thomas, US Virgin Islands, United States of America & CCFHR & CCFHR & 103,300 & [68] \\
\hline \multirow{5}{*}{ G. caribaeus } & CCMP1733 (NOAA11) & Carrie Bow Cay, Belize, Caribbean, United States of America & NCMA & PHYC & 282,450 & [58] \\
\hline & Bill Hi Gam8 & Waikiki Beach, Honolulu, Hawaii, United States of America & CCFHR & CCFHR & 110,600 & [69] \\
\hline & CCMP1651 (NOAA20) & $\begin{array}{l}\text { Grand Cayman Island, Caribbean, Territory of United } \\
\text { Kingdom }\end{array}$ & NCMA & CCFHR & 62,300 & [58] \\
\hline & Dive $1 \mathrm{fa}$ Gam 1 & Ft. Pierce, Florida, United States of America & CCFHR & CCFHR & 378,000 & [68] \\
\hline & Mexico Algae1 Gam1 & Cancun, Mexico & CCFHR & CCFHR & 123,395 & [68] \\
\hline \multirow{3}{*}{ G. carolinianus } & ETB Exp28 Gam10 & Dry Tortugas, United States of America & CCFHR & CCFHR & 61,005 & [68] \\
\hline & Greece Gam2 & Crete, Greece & CCFHR & CCFHR & 82,775 & [69] \\
\hline & RROV5 & Puerto Rico, United States of America & CCFHR & CCFHR & 116,985 & [68] \\
\hline \multirow{4}{*}{ G. carpenteri } & GT4 & Carrie Bow Cay, Belize & CCFHR & CCFHR & 88,000 & {$[57,68]$} \\
\hline & Jamaica Algae2 Gam1 & Ocho Rios, Jamaica & CCFHR & CCFHR & 98,250 & [68] \\
\hline & Pat Hi Jar7 Gam11 & Waikiki Beach, Honolulu, Hawaii, United States of America & CCFHR & CCFHR & 59,680 & {$[57,69]$} \\
\hline & WHBR21 & $\begin{array}{l}\text { Flower Garden Banks National Marine Sanctuary (West Bank), } \\
\text { Northwestern Gulf of Mexico, United States of America }\end{array}$ & CCFHR & CCFHR & 96,720 & {$[68]$} \\
\hline
\end{tabular}


Table 5. Cont

\begin{tabular}{|c|c|c|c|c|c|c|}
\hline Species/Phylotype & Strain & Geographical Origin & $\begin{array}{c}\text { Culture } \\
\text { Collection }\end{array}$ & $\begin{array}{c}\text { Culture } \\
\text { Conditions }\end{array}$ & $\begin{array}{c}\text { Number of } \\
\text { Cells Extracted }\end{array}$ & Reference \\
\hline \multirow{7}{*}{ G. excentricus } & Pulley Ridge Gam 2 & Pulley Ridge, Florida, United States of America & CCFHR & CCFHR & $1,630,000$ & [75] \\
\hline & UNR-07 & Armação dos Búzios, Rio de Janeiro, Brazil & UNIRIO & UNIRIO & $1,013,833$ & [79] \\
\hline & UNR-08 & Armação dos Búzios, Rio de Janeiro, Brazil & UNIRIO & UNIRIO & 441,490 & [79] \\
\hline & VGO1035 & Playa Las Cabras, La Palma, Canary Islands, Spain) & CCVIEO & PHYC & 242,050 & [61] \\
\hline & VGO790 & Punta Hidalgo, Tenerife, Canary Islands, Spain & CCVIEO & PHYC & 171,711 & [61] \\
\hline & VGO791 & Punta Hidalgo, Tenerife, Canary Islands, Spain & CCVIEO & PHYC & $2,200,160$ & [61] \\
\hline & VGO792 & Punta Hidalgo, Tenerife, Canary Islands, Spain & CCVIEO & PHYC & $2,159,997$ & [61] \\
\hline \multirow{2}{*}{ G. pacificus } & CCMP1650 (NOAA 9) (MR1) & Moorea, Society Islands, French Polynesia & NCMA & PHYC & 630,175 & [58] \\
\hline & G10DC & Malaysia & IRTA & PHYC & 965,040 & {$[80]$} \\
\hline \multirow{4}{*}{$\begin{array}{l}\text { Gambierdiscus sp. } \\
\text { ribotype } 2\end{array}$} & CCMP1655 (MQ2) & Martinique, Caribbean, insular region of France & NCMA & PHYC & 109,080 & [89] \\
\hline & Mixed PR & Puerto Rico, United States of America & CCFHR & CCFHR & 98,560 & [75] \\
\hline & St Maartens Gam10 & St. Maarteens, Kingdom of the Netherlands & CCFHR & CCFHR & 116,000 & [75] \\
\hline & SW Algae Gam1 & Southwater Cay, Belize & CCFHR & CCFHR & 76,410 & [75] \\
\hline G. scabrosus & KW070922_1 & Kashiwa-jima Island, Otsuki, Kochi, Japan & KU & PHYC & 771,711 & {$[63,87]$} \\
\hline \multirow{3}{*}{ G. silvae } & UNR-30 & Brazil & UNIRIO & UNIRIO & 362,877 & $\begin{array}{c}\text { Unpublished } \\
\text { strain }\end{array}$ \\
\hline & VGO1167 & Punta Hidalgo, Tenerife, Canary Islands, Spain & CCVIEO & PHYC & 502,080 & [62] \\
\hline & VGO1180 & Punta Hidalgo, Tenerife, Canary Islands, Spain & CCVIEO & PHYC & 421,430 & [62] \\
\hline Gambierdiscus sp. & Viet Nam & Cau Island, Binh Thuan, South China Sea, Viet Nam & VNIO & PHYC & $1,726,949$ & {$[67,83,90]$} \\
\hline \multirow{3}{*}{ G. toxicus } & GTT-91 & Teahupoo, Tahiti, French Polynesia & CCFHR & CCFHR & 116,625 & [70] \\
\hline & HIT-0 & Hitiaa, Tahiti, French Polynesia & CCFHR & CCFHR & 106,650 & [70] \\
\hline & HIT-25 & Hitiaa, Tahiti, French Polynesia & CCFHR & CCFHR & 74,800 & {$[70]$} \\
\hline
\end{tabular}




\subsection{Fractionation of Gambierdiscus excentricus VGO791 and VGO792}

After three weeks of semi-continuous culture [69], cells were first filtered on a $25 \mu \mathrm{m}$ sieve, then harvested by centrifugation $\left(20 \mathrm{~min}, 3000 \mathrm{~g}, 4{ }^{\circ} \mathrm{C}\right)$ in $50 \mathrm{~mL}$ Falcon ${ }^{\circledR}$ tubes. A total of 2.20 million cells (3.307 g wet pellet, $4.5 \mathrm{~L}$ of culture, 15 flasks) and 2.16 million cells ( $3.076 \mathrm{~g}$ wet pellet, $4.5 \mathrm{~L}$ of culture, 15 flasks) were harvested for G. excentricus VGO791 and VGO792, respectively. Cell pellets were stored at $-20^{\circ} \mathrm{C}$ until further extraction for toxicity screening and chemical analyses. After the cells had been harvested in log phase growth, they were extracted as described above (Section 4.3). An aliquot of crude extract volume was filtered through a Nanosep MF $0.2 \mu \mathrm{m}$ filter and stored at $-20^{\circ} \mathrm{C}$ until cellular bioassays and LC-MS analyses. The remnant part was evaporated under $\mathrm{N}_{2}$ at $40{ }^{\circ} \mathrm{C}$ and stored at $-20{ }^{\circ} \mathrm{C}$.

\subsubsection{Liquid-Liquid Partitioning}

The residues of crude extracts ( $0.263 \mathrm{~g}$ for G. excentricus VGO791 and $0.251 \mathrm{~g}$ for G. excentricus VGO792) were suspended in dichloromethane (50 mL per 1 million cells) and partitioned twice with $\mathrm{MeOH}: \mathrm{H}_{2} \mathrm{O}(3: 2, v / v)(25 \mathrm{~mL}$ per 1 million cells) as previously described by Satake, et al. [91]. Maitotoxins are supposed to partition into the aqueous methanol soluble fraction (MSF). Once the MSF was isolated, it was blown dry under $\mathrm{N}_{2}$ gas at $40{ }^{\circ} \mathrm{C}$ and stored at $-20^{\circ} \mathrm{C}$. The dried MSF residue was re-dissolved in $1.5 \mathrm{~mL} \mathrm{MeOH}: \mathrm{H}_{2} \mathrm{O}(1: 1, v / v)$ and filtered through a Nanosep MF $0.2 \mu \mathrm{m}$ filter.

\subsubsection{Size-Exclusion Chromatography (SEC): Sephadex ${ }^{\mathrm{TM}} \mathrm{LH}-20$}

Prior to use, Sephadex ${ }^{\mathrm{TM}} \mathrm{LH}-20$ powder $(10 \mathrm{~g})$ was swollen in methanol $(\mathrm{MeOH})$ over one night, then gently packed in a glass open column (intern diameter: $1 \mathrm{~cm}$ ) in one continuous motion and finally rinsed with $\mathrm{MeOH}$. Bed height was $52.7 \mathrm{~cm}$, hence bed volume was calculated to be $41.4 \mathrm{~mL}$. An aliquot of MSFs of G. excentricus VGO791 ( $0.745 \mathrm{~mL}, 1.082$ million cells, $32.5 \mathrm{mg}$ MSF residue) and G. excentricus VGO792 (0.700 mL, 0.998 million cells, $29.9 \mathrm{mg}$ MSF residue) were separately deposited on the top of the LH-20 column; compounds were then eluted with $\mathrm{MeOH}$ under atmospheric pressure (flow rate: $0.4 \mathrm{~mL} \mathrm{~min}^{-1}$ ). Eluting fractions were collected as follows: 50 fractions of $2.5 \mathrm{~mL}$ each for $\mathrm{G}$. excentricus VGO791; 1st fraction of $10 \mathrm{~mL}, 45$ fractions of $1 \mathrm{~mL}$ and two last fractions of $30 \mathrm{~mL}$ for G. excentricus VGO792. All the fractions were screened for toxicity (N2a assays), and analyzed by LC-MS at either high or low resolutions, in either HRMS full scan or targeted HRMS/MS and LRMS/MS modes.

\subsection{Neuroblastoma Neuro-2a (N2a) Assays}

\subsubsection{N2a Cytotoxicity Assay}

The N2a cytotoxicity assay was performed at the Phycotoxins Laboratory (Ifremer, Nantes, France) using the protocol for MTX detection described by Caillaud, et al. [92].

The N2a cell line was obtained from the American Type Culture Collection (ATCC, CCL 131). N2a cells were grown and maintained as described by Hardison, et al. [93]. The assay was carried out in 96-well flat-bottom Falcon ${ }^{\circledR}$ tissue culture plates with vacuum gas plasma treatment for cell adhesion (Dominique DUTSCHER SAS, Brumath, France). Plates were seeded with 30,000 N2a cells per well and were incubated for $24 \mathrm{~h}$ until they were $>90 \%$ confluent at the bottom of each well. The MTX standard, controls and G. excentricus samples were added next and incubated for $2.5 \mathrm{~h}$. The 6-point MTX standard curve for this assay ranged from 0.29 to $29,127 \mathrm{ng} \mathrm{mL}^{-1}$ per well. Controls included buffer wells to provide maximum survival estimates and wells with the addition of $3 \% \mathrm{MeOH}$ (final concentration in well) to identify any cell mortality caused by the presence of $\mathrm{MeOH}$ used to dissolve the samples. The following sample aliquots ( $3 \mu \mathrm{L}$ additions) were tested: MSF extracts of G. excentricus VGO791 and VGO792 and their respective fractions obtained by SEC (LH-20). Total well volume was hence $103 \mu \mathrm{L}$.

For each sample, six 10-fold serial dilutions were tested in three separate experiments and three replicate wells for each dilution were run for each experiment. Sigmoidal dose-response curves were plotted using the four-parameter logistic model (4PL) and $\mathrm{EC}_{50}$ values (cell eq $\mathrm{mL}^{-1}$ ) were calculated for each sample using SigmaPlot ${ }^{\circledR} 12$. Quantitation of MTX eq in the samples using the N2a cytotoxicity 
assay was calculated by converting $\mathrm{EC}_{50}$ values (cell eq $\mathrm{mL}^{-1}$ ) into toxin equivalent per cell (pg MTX eq cell ${ }^{-1}$ ) taking into account the $\mathrm{EC}_{50}$ value obtained from the MTX standard curve. Results were then converted in $\mu \mathrm{g}$ MTX eq multiplying for the initial number of cells extracted.

Cell viability was assessed after $2.5 \mathrm{~h}$ incubation using the quantitative colorimetric 3-(4,5-dimethylthiazol-2-yl)-2,5-diphenyl tetrazolium bromide (MTT) assay [94] using a Tecan Infinite ${ }^{\circledR}$ M200 plate reader (Tecan Austria GmbH, Grödig, Austria) at $544 \mathrm{~nm}$. The viability of cells treated with MTX standard or algal extracts was estimated relative to control wells in solvent vehicle $(3 \% \mathrm{MeOH}$ in N2a medium).

\subsubsection{N2a Calcium Flux Assay}

The high-content screening (HCS) assay employed an automated epifluorescence microscopy and image analysis of cells in a microtiter plate format $[95,96]$. In the present study, HCS assay was used to measure $\mathrm{Ca}^{2+}$ influx induced by MTXs using the N2a cell line. The assay was performed at the Toxicology of Contaminants Unit, ANSES Laboratory (Fougères, France).

N2a cells (ATCC, CCL 131) were grown and maintained as described by Sérandour et al. [97]. The assay was carried out in Nunc 96-well thin bottom microplates (Thermo Scientific, Waltham, MA, USA). Each well was seeded with 33,000 N2a cells and plates were incubated for $24 \mathrm{~h}$ until they were $>90 \%$ confluent at the bottom of each well. Next, two fluorescent dyes, Hoechst $33342\left(3 \mu \mathrm{g} \mathrm{mL}^{-1}\right)$ for cell nuclei staining and Fluo-4-AM $(5 \mu \mathrm{M})$ for ${ }_{\mathrm{i}} \mathrm{Ca}^{2+}$ staining, were added to each well and the plates were placed back in the incubator for $40 \mathrm{~min}$.

Vehicle control solution for the assay consisted of N2a culture medium without fetal calf serum (FCS) containing 5\% MeOH. The MTX standard curve for the assay ranged from 26.7 to $102,776 \mathrm{pg} \mathrm{mL}^{-1}$ in well (from 7.81 to $30,000 \mathrm{pM}$ ) and was prepared in FCS-free N2a culture medium containing $5 \% \mathrm{MeOH}$. The crude extract and partially purified extracts from G. excentricus VGO791 were prepared as follows: $0.05 \mathrm{~mL}$ of each sample were diluted in $0.95 \mathrm{~mL}$ of FCS-free N2a culture medium resulting in a solution with final $\mathrm{MeOH}$ content of $5 \%$.

Six wells per plate were dedicated to vehicle control exposure to identify any non-specific flux of $\mathrm{Ca}^{2+}$ due to the presence of $5 \% \mathrm{MeOH}$. For each sample, three separate experiments were performed, and each experiment was run in three replicate wells. N2a medium was discarded from the wells, one-by-one, and immediately replaced with $100 \mu \mathrm{L}$ of vehicle control, MTX standard or G. excentricus VGO791 samples just before the fluorescence measurement. Fluorescence ( $388 \mathrm{~nm}$ for cell nuclei, $488 \mathrm{~nm}$ for ${ }_{\mathrm{i}} \mathrm{Ca}^{2+}$ ) was followed in real-time with one image per $1.5 \mathrm{~min}$ frame rate using an ArrayScan VTI HCS Reader (Thermo Scientific, Waltham, MA, USA) with $10 \times$ objective. Intracellular calcium signal was assessed after 4.5 min exposure and expressed as a fold of intensity compared to control treatment ( $5 \% \mathrm{MeOH}$ in FCS-free N2a culture medium).

\subsection{LC-MS Analyses}

\subsubsection{LC-HRMS and HRMS/MS (Q-Tof 6550 iFunnel)}

LC-HRMS analyses were performed at the Phycotoxins Laboratory (Ifremer, Nantes, France) using a UHPLC system 1290 Infinity II (Agilent Technologies, Santa Clara, CA, USA) coupled to a high resolution time-of-flight mass spectrometer Q-Tof 6550 iFunnel (Agilent Technologies, Santa Clara, CA, USA) equipped with a Dual Jet Stream ${ }^{\circledR}$ electrospray ionization (ESI) interface operating in negative mode. Toxins were separated using a reversed-phase $C_{18}$ Kinetex column $(100 \AA, 2.6 \mu \mathrm{m}$, $50 \times 2.1 \mathrm{~mm}$, Phenomenex, Le Pecq, France) with water (A) and 95\% acetonitrile/water (B). The column oven and the sample tray temperatures were set at $40{ }^{\circ} \mathrm{C}$ and $4{ }^{\circ} \mathrm{C}$, respectively. The flow rate was set at $0.4 \mathrm{~mL} \mathrm{~min}^{-1}$, the injection volume was set at $3 \mu \mathrm{L}$. Separation was achieved using the following mobile phase gradient: from 10 to $95 \%$ B in $10 \mathrm{~min}$, plateau at $95 \%$ B for 2 min, return to the initial condition $(10 \% \mathrm{~B})$ in $0.1 \mathrm{~min}$ and a re-equilibration period $(10 \% \mathrm{~B})$ for $3.9 \mathrm{~min}$. The 
chromatographic run lasted 16 min per analysis. The MTX standard used for LC-HRMS experiments was at a concentration of $20 \mu \mathrm{g} \mathrm{mL}-1 \mathrm{MeOH}^{-\mathrm{H}_{2} \mathrm{O}}(1: 1, v / v)$.

The conditions of the ESI source were set as follows: source temperature, $200{ }^{\circ} \mathrm{C}$; drying gas, $\mathrm{N}_{2}$; flow rate, $11 \mathrm{~mL} \mathrm{~min}^{-1}$; sheath gas temperature, $350^{\circ} \mathrm{C}$; sheath gas flow rate, $11 \mathrm{~mL} \mathrm{~min}^{-1}$; nebulizer, 45 psig; capillary voltage, $-3.5 \mathrm{kV}$; nozzle voltage, $500 \mathrm{~V}$. The instrument was mass calibrated in negative ionization mode before each analysis, using the Agilent tuning mix. A mixture solution of reference mass compounds (purine, $2 \mathrm{~mL} \mathrm{~L}^{-1}$; HP-0921, $1 \mathrm{~mL} \mathrm{~L}^{-1}$; HP-1221, $1 \mathrm{~mL} \mathrm{~L}^{-1}$; HP-1821, $2 \mathrm{~mL} \mathrm{~L}^{-1}$; HP-2421, $\left.2 \mathrm{~mL} \mathrm{~L}^{-1}\right)$ in $\mathrm{MeOH}: \mathrm{H}_{2} \mathrm{O}(95: 5, v / v)$ was infused with an isocratic pump to a separate ESI sprayer in the dual spray source at a constant flow rate of $1.5 \mu \mathrm{L} \mathrm{min}{ }^{-1}$. Purine and HP-0921 allowed for correction of the measured $\mathrm{m} / \mathrm{z}$ throughout the batch.

Mass spectrum detection was carried out in full scan and targeted MS/MS mode in negative ion acquisition. The full scan acquisition operated at a mass resolution of 45,000 Full Width at Half Maximum (FWHM) over a mass-to-charge ratio $(\mathrm{m} / \mathrm{z})$ range from 100 to 3200 with a scan rate of 2 spectra s$^{-1}$. The LOD (S/N ratio > 3) calculated for MTX (negative mode EIC of $1688.8013 \mathrm{~m} / \mathrm{z}$ ) was $1.88 \mu \mathrm{g} \mathrm{mL}{ }^{-1}$. The targeted MS/MS mode was performed in a Collision Induced Dissociation cell using a mass resolving power of 45,000 FWHM over the scan range $m / z$ from 50 to 3200 with a MS

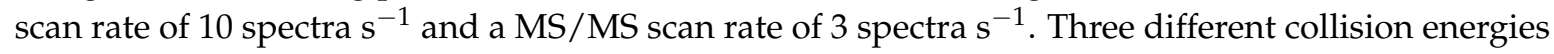
were applied to the precursor ions to obtain a good fragmentation pathway.

All the acquisition and analysis data were controlled by MassHunter software (Agilent Technologies, Santa Clara, CA, USA). Raw data were processed using the Molecular Feature Extraction (MFE) algorithm of the Agilent MassHunter Qualitative Analysis software, version B.07.00, service pack 1 (Agilent Technologies, Santa Clara, CA, USA). The algorithm performs all tasks related to "peak-picking" and thus allowed for identification of all sample components down to the lowest-level abundance (abundance cut-off set at 500 counts) and to extract all relevant spectral and chromatographic information. Data-mining was carried out to manage data complexity and to correlate MS data to toxicity.

\subsubsection{LC-LRMS/MS (API 4000 QTrap)}

LC-LRMS/MS experiments to monitor specific MTX congeners in the methanolic extracts obtained from the strains listed in Table 5 were performed at the Phycotoxins Laboratory (Ifremer, Nantes, France) using a LC system (UFLC XR Nexera, Shimadzu, Japan) coupled to a hybrid triple quadrupole/ion-trap mass spectrometer API 4000 QTrap (SCIEX, Redwood City, CA, USA) equipped with a turboV ${ }^{\circledR}$ ESI source. Toxins were separated using the same chromatographic conditions as described above (Section 4.6.1). The injection volume was set at $5 \mu \mathrm{L}$. Mass spectrum detection was carried out in negative ion acquisition mode using multiple reactions monitoring (MRM).

The MTX standard calibration range for the LC-LRMS/MS experiments consisted of nine concentrations ranging from 0.1 to $20 \mu \mathrm{gL}^{-1} \mathrm{MeOH}: \mathrm{H}_{2} \mathrm{O}(1: 1, v / v)$. MRM experiments were established using the following source settings: curtain gas set at $25 \mathrm{psi}$, ion spray at $-4.5 \mathrm{kV}$, a turbogas temperature of $300{ }^{\circ} \mathrm{C}$, gas 1 and 2 set, respectively, at 40 and $60 \mathrm{psi}$, an entrance and declustering potential of $-10 \mathrm{~V}$ and $-210 \mathrm{~V}$, respectively. The limit of detection (LOD) and the limit of quantification (LOQ) were determined with the ordinary least-squares regression data method $[98,99]$ using the lowest 3 points from the calibration curves. The LOD was calculated as 3 times the standard deviation of the y-intercepts over the slope of the calibration curve; the LOQ was calculated as 10 times the standard deviation of the y-intercepts over the slope of the calibration curve $[98,99]$.

The fragment ion monitored for all the MRM transition of the MTX-group of toxins was the hydrogenated sulfate anion $\left[\mathrm{HOSO}_{3}\right]^{-}(\mathrm{m} / z$ 96.9). The precursor ions were chosen according to data available in literature or provided in this study. Seven and six MRM transitions $(m / z)$, were monitored for MTX and MTX4, respectively, to permit the best toxin identification (Table 6) with a dwell time of 80 msec. Quantification of MTX and MTX4 was operated using the MRM transition $[\mathrm{M}-2 \mathrm{H}]^{2-} \rightarrow$ $[\mathrm{M}-2 \mathrm{H}]^{2-}$. MTX4 was quantified over the MTX calibration curve, assuming equal molar response 
and applying the same LOD and LOQ calculated for MTX. In the absence of MS/MS data on MTX2, precursor ions $(m / z)$ were selected according to Lewis et al. [56]. Bi-charged and tri-charged molecular anions were also calculated and added to the MRM method (Table 6). For MTX3, the lack of MS data in negative ion acquisition mode did not allow the selection of precursor ions $(\mathrm{m} / \mathrm{z})$ which were already described in literature. In the present study, a MRM transition involving $[\mathrm{M}+\mathrm{Na}-2 \mathrm{H}]^{-}$as precursor ion was selected according to a previous study conducted by Kohli et al. [72]. MRM transitions in this study also involved the corresponding molecular mono-charged anion $[\mathrm{M}-\mathrm{H}]^{-}$(calculated $\mathrm{m} / \mathrm{z}$ 1015.5), its di-sodium adduct (calculated $m / z$ 1057.5) and the molecular bi-charged anion $[\mathrm{M}-2 \mathrm{H}]^{2-}$ (calculated $m / z$ 507.3) as precursor ions (Table 6).

Table 6. List of the MRM transitions $(m / z)$ for the four MTXs known to date (LC-LRMS/MS, API 4000 QTrap). MRM transitions of MTX and MTX4 were chosen according to HRMS data provided in this study. Quantification of MTX and MTX4 was operated using the MRM transition $[\mathrm{M}-2 \mathrm{H}]^{2-} \rightarrow[\mathrm{M}$ $-2 \mathrm{H}]^{2-}$ (in bold). In the absence of MS/MS data on maitotoxin-2 (MTX2) and maitotoxin-3 (MTX3), putative MRM transitions were chosen based on their MS spectral peaks reported in literature and assuming that they share the same fragmentation behavior as that of MTX and MTX4. * $=\mathrm{M}$ refers to the free acid form, i.e., without the sodium salt(s) on sulfate ester group(s), e.g., $\mathrm{M}=\mathrm{C}_{164} \mathrm{H}_{258} \mathrm{O}_{68} \mathrm{~S}_{2}$ for MTX.

\begin{tabular}{|c|c|c|c|c|}
\hline \multirow[t]{2}{*}{ Compound } & \multicolumn{2}{|c|}{ MRM Transitions $(m / z) *$} & \multirow{2}{*}{$\begin{array}{c}\mathrm{CE}(\mathrm{eV}) \\
-40\end{array}$} & \multirow{2}{*}{$\frac{\mathrm{CXP}(\mathbf{e V})}{-15}$} \\
\hline & {$[\mathrm{M}-2 \mathrm{H}]^{2-} /[\mathrm{M}-2 \mathrm{H}]^{2-}$} & $1689.8 / 1689.8$ & & \\
\hline \multirow{6}{*}{ MTX } & {$[\mathrm{M}-2 \mathrm{H}]^{2-} /\left[\mathrm{HOSO}_{3}\right]^{-}$} & $1689.8 / 96.9$ & -125 & -21 \\
\hline & {$[\mathrm{M}+\mathrm{Na}-3 \mathrm{H}]^{2-} /\left[\mathrm{HOSO}_{3}\right]^{-}$} & $1700.8 / 96.9$ & -125 & -21 \\
\hline & {$[\mathrm{M}+2 \mathrm{Na}-3 \mathrm{H}]^{2-} /\left[\mathrm{HOSO}_{3}\right]^{-}$} & $1711.8 / 96.9$ & -125 & -21 \\
\hline & {$[\mathrm{M}-3 \mathrm{H}]^{3-} /[\mathrm{M}-3 \mathrm{H}]^{3-}$} & $1126.2 / 1126.2$ & -40 & -15 \\
\hline & {$[\mathrm{M}-3 \mathrm{H}]^{3-} /\left[\mathrm{HOSO}_{3}\right]^{-}$} & $1126.2 / 96.9$ & -125 & -21 \\
\hline & {$[\mathrm{M}-4 \mathrm{H}]^{4-} /\left[\mathrm{HOSO}_{3}\right]^{-}$} & $844.4 / 96.9$ & -125 & -21 \\
\hline \multirow{6}{*}{ MTX2 } & {$[\mathrm{M}-2 \mathrm{H}]^{2-} /\left[\mathrm{HOSO}_{3}\right]^{-}$} & $1637.5 / 96.9$ & -125 & -21 \\
\hline & {$[\mathrm{M}+\mathrm{Na}-3 \mathrm{H}]^{2-} /\left[\mathrm{HOSO}_{3}\right]^{-}$} & $1648.2 / 96.9$ & -125 & -21 \\
\hline & {$[\mathrm{M}+\mathrm{K}-3 \mathrm{H}]^{2-} /\left[\mathrm{HOSO}_{3}\right]^{-}$} & $1656.0 / 96.9$ & -125 & -21 \\
\hline & {$[\mathrm{M}-3 \mathrm{H}]^{3-} /\left[\mathrm{HOSO}_{3}\right]^{-}$} & $1091.5 / 96.9$ & -125 & -21 \\
\hline & {$[\mathrm{M}+\mathrm{Na}-4 \mathrm{H}]^{3-} /\left[\mathrm{HOSO}_{3}\right]^{-}$} & $1098.6 / 96.9$ & -125 & -21 \\
\hline & {$[\mathrm{M}+\mathrm{K}-4 \mathrm{H}]^{3-} /\left[\mathrm{HOSO}_{3}\right]^{-}$} & 1103.8/96.9 & -125 & -21 \\
\hline \multirow{4}{*}{ MTX3 } & {$[\mathrm{M}-\mathrm{H}]^{-} /\left[\mathrm{HOSO}_{3}\right]^{-}$} & $1015.5 / 96.9$ & -125 & -21 \\
\hline & {$[\mathrm{M}+\mathrm{Na}-2 \mathrm{H}]^{-} /\left[\mathrm{HOSO}_{3}\right]^{-}$} & $1037.6 / 96.9$ & -125 & -21 \\
\hline & {$[\mathrm{M}+2 \mathrm{Na}-3 \mathrm{H}]^{-} /\left[\mathrm{HOSO}_{3}\right]^{-}$} & $1057.5 / 96.9$ & -125 & -21 \\
\hline & {$[\mathrm{M}-2 \mathrm{H}]^{2-} /\left[\mathrm{HOSO}_{3}\right]^{-}$} & $507.3 / 96.9$ & -125 & -21 \\
\hline \multirow{6}{*}{ MTX4 } & {$[\mathbf{M}-2 \mathrm{H}]^{2-} /[\mathrm{M}-2 \mathrm{H}]^{2-}$} & $1646.2 / 1646.2$ & -40 & -15 \\
\hline & {$[\mathrm{M}-2 \mathrm{H}]^{2-} /\left[\mathrm{HOSO}_{3}\right]^{-}$} & $1646.2 / 96.9$ & -125 & -21 \\
\hline & {$[\mathrm{M}+\mathrm{Na}-3 \mathrm{H}]^{2-} /\left[\mathrm{HOSO}_{3}\right]^{-}$} & $1657.2 / 96.9$ & -125 & -21 \\
\hline & {$[\mathrm{M}+2 \mathrm{Na}-3 \mathrm{H}]^{2-} /\left[\mathrm{HOSO}_{3}\right]^{-}$} & $1668.2 / 96.9$ & -125 & -21 \\
\hline & {$[\mathrm{M}-3 \mathrm{H}]^{3-} /[\mathrm{M}-3 \mathrm{H}]^{3-}$} & $1097.1 / 1097.1$ & -40 & -15 \\
\hline & {$[\mathrm{M}-3 \mathrm{H}]^{3-} /\left[\mathrm{HOSO}_{3}\right]^{-}$} & 1097.1/96.9 & -125 & -21 \\
\hline
\end{tabular}

Supplementary Materials: The following are available online at www.mdpi.com/1660-3397/15/7/220/s1, Figure S1. Sigmoidal dose-response curve of MTX standard on the neuroblastoma N2a cytotoxicity assay after 2.5 $\mathrm{h}$ exposure. Error bars represent assay variability (standard deviation, SD) measured by running extracts in three separate assays. In each assay, three separate wells were used for assaying each fraction. Figure S2. Sigmoidal dose-response curve of MTX standard on the N2a-based HCS assay for $\mathrm{Ca}^{2+}$ flux after 4.5 min exposure. $\mathrm{Ca}^{2+}$ flux was estimated measuring the fluorescence of the Fluo-4-AM dye at $488 \mathrm{~nm}$. Fluo-4-AM fluorescence was expressed as a fold of intensity compared to vehicle control condition (5\% MeOH in FCS-free N2a medium). Error bars represent assay variability (standard deviation, SD) measured by running extracts in three separate assays. In each assay, three separate wells were used for assaying each fraction.

Acknowledgments: The authors acknowledge Ifremer and the Regional Council of the Région des Pays de la Loire for Ph.D. funding of F. Pisapia. S. Fraga thanks MINECO for funding project CICAN. The authors would 
like to thank Luiz Mafra Jr. for establishing contacts between several of the authors and the International Atomic Energy Agency (IAEA) for funding through the Core Research Project CRP-K41014. The authors gratefully acknowledge Masao Adachi and Tomohiro Nishimura for the provision of the two Gambierdiscus strains G. scabrosus (KW070922_1) and G. australes (S080911_1).

Author Contributions: F.P., M.S., C.H. and P.H. conceived and designed the experiments; F.P. and G.G. performed: cultures of Gambierdiscus, cell pellet extraction, size-exclusion chromatography and cytotoxicity screening via N2a cytotoxicity assay; F.P. and K.L. performed the cultures of N2a cells; F.P., V.F. and P.-J.F. designed and performed the N2a Ca ${ }^{2+}$ flux high-content screening (HCS) assay experiments; F.P., M.S., P.H. and C.H. performed and analyzed the HRMS/MS and LRMS/MS data; S.F., S.M.N. and W.C.H. contributed some of the strains and culture material used in this study, V.F., C.R. contributed reagents, materials and data analysis; F.P. wrote the paper; V.F., C.R., R.W.L., C.H. and P.H. corrected and revised the paper.

Conflicts of Interest: The authors declare no conflict of interest. The funding sponsors had no role in the design of the study; in the collection, analyses, or interpretation of data; in the writing of the manuscript, and in the decision to publish the results.

\section{References}

1. Murata, M.; Naoki, H.; Iwashita, T.; Matsunaga, S.; Sasaki, M.; Yokoyama, A.; Yasumoto, T. Structure of maitotoxin. J. Am. Chem. Soc. 1993, 115, 2060-2062. [CrossRef]

2. Kelley, B.A.; Jollow, D.J.; Felton, E.T.; Voegtline, M.S.; Higerd, T.B. Response of mice to Gambierdiscus toxicus toxin. Mar. Fish. Rev. 1986, 48, 35-37.

3. Kohli, G.S.; Papiol, G.G.; Rhodes, L.L.; Harwood, D.T.; Selwood, A.; Jerrett, A.; Murray, S.A.; Neilan, B.A. A feeding study to probe the uptake of maitotoxin by snapper (Pagrus auratus). Harmful Algae 2014, 37, 125-132. [CrossRef]

4. Yasumoto, T.; Bagnis, R.; Vernoux, J. Toxicity of the surgeonfishes II. Properties of the principal water-soluble toxin. Bull. Jpn. Soc. Sci. Fish 1976, 42, 359-365. [CrossRef]

5. Yasumoto, T.; Hashimoto, Y.; Bagnis, R.; Randall, J.E.; Banner, A.H. Toxicity of the surgeonfishes. Nippon Suisan Gakkaishi 1971, 37, 724-734. [CrossRef]

6. Yasumoto, T.; Seino, N.; Murakami, Y.; Murata, M. Toxins produced by benthic dinoflagellates. Biol. Bull. 1987, 172, 128-131. [CrossRef]

7. Murata, M.; Naoki, H.; Matsunaga, S.; Satake, M.; Yasumoto, T. Structure and partial stereochemical assignments for maitotoxin, the most toxic and largest natural non-biopolymer. J. Am. Chem. Soc. 1994, 116, 7098-7107. [CrossRef]

8. Murata, M.; Yasumoto, T. The structure elucidation and biological activities of high molecular weight algal toxins: Maitotoxin, prymnesins and zooxanthellatoxins. Nat. Prod. Rep. 2000, 17, 293-314. [CrossRef] [PubMed]

9. Yokoyama, A.; Murata, M.; Oshima, Y.; Iwashita, T.; Yasumoto, T. Some chemical properties of maitotoxin, a putative calcium channel agonist isolated from a marine dinoflagellate. J. Biochem. 1988, 104, 184-187. [CrossRef] [PubMed]

10. Gusovsky, F.; Daly, J.W. Maitotoxin: A unique pharmacological tool for research on calcium-dependent mechanisms. Biochem. Pharmacol. 1990, 39, 1633-1639. [CrossRef]

11. Reyes, J.G.; Sánchez-Cárdenas, C.; Acevedo-Castillo, W.; Leyton, P.; López-González, I.; Felix, R.; Gandini, M.A.; Treviño, M.B.; Treviño, C.L. Maitotoxin: An enigmatic toxic molecule with useful applications in the biomedical sciences. In Seafood and Freshwater Toxins: Pharmacology, Physiology and Detection; Botana, L.M., Ed.; CRC Press (Taylor \& Francis Group): Boca Raton, FL, USA, 2014; pp. 677-694.

12. Ogura, A.; Ohizumi, Y.; Yasumoto, T. Calcium-dependent depolarization induced by a marine toxin, maitotoxin, in a neuronal cell. Jpn. J. Pharmacol. 1984, 36, P315.

13. Gusovsky, F.; Bitran, J.A.; Yasumoto, T.; Daly, J.W. Mechanism of maitotoxin-stimulated phosphoinositide breakdown in HL-60 cells. J. Pharmacol. Exp. Ther. 1990, 252, 466-473. [PubMed]

14. Ohizumi, Y.; Yasumoto, T. Contraction and increase in tissue calcium content induced by maitotoxin, the most potent known marine toxin, in intestinal smooth muscle. Br. J. Pharmacol. 1983, 79, 3-5. [CrossRef] [PubMed]

15. Ohizumi, Y.; Yasumoto, T. Contractile response of the rabbit aorta to maitotoxin, the most potent marine toxin. J. Physiol. Lond. 1983, 337, 711-721. [CrossRef] [PubMed] 
16. Ohizumi, Y.; Kajiwara, A.; Yasumoto, T. Excitatory effect of the most potent marine toxin, maitotoxin, on the guinea-pig vas deferens. J. Pharmacol. Exp. Ther. 1983, 227, 199-204. [PubMed]

17. Treviño, C.L.; De la Vega-Beltrán, J.L.; Nishigaki, T.; Felix, R.; Darszon, A. Maitotoxin potently promotes $\mathrm{Ca}^{2+}$ influx in mouse spermatogenic cells and sperm, and induces the acrosome reaction. J. Cell. Physiol. 2006, 206, 449-456. [CrossRef] [PubMed]

18. Nishiyama, I.; Matsui, T.; Yasumoto, T.; Oshio, S.; Hoshi, M. Maitotoxin, a presumed calcium-channel activator, induces the acrosome reaction in mussel spermatozoa. Dev. Growth Differ. 1986, 28, 443-448. [CrossRef]

19. Amano, T.; Okita, Y.; Yasumoto, T.; Hoshi, M. Maitotoxin induces acrosome reaction and histone degradation of starfish Asterina pectinifera sperm. Zool. Sci. 1993, 10, 307-312.

20. Taglialatela, M.; Amoroso, S.; Yasumoto, T.; Di Renzo, G.; Annunziato, L. Maitotoxin and Bay-K-8644: Two putative calcium channel activators with different effects on endogenous dopamine release from tuberoinfundibular neurons. Brain Res. 1986, 381, 356-358. [CrossRef]

21. Ohizumi, Y.; Kajiwara, A.; Yasumoto, T. Mode of the noradrenaline release induced by maitotoxin, the principal toxin of poisonous fishes inhabiting tropical seas, from adrenergic nerves. Folia Pharmacol. Jpn. 1983, 82, 158.

22. Takahashi, M.; Tatsumi, M.; Ohizumi, Y.; Yasumoto, T. $\mathrm{Ca}^{2+}$ channel activating function of maitotoxin, the most potent marine toxin known, in clonal rat pheochromocytoma cells. J. Biol. Chem. 1983, 258, 944-949.

23. Pin, J.-P.; Yasumoto, T.; Bockaert, J. Maitotoxin-evoked X-aminobutyric acid release is due not only to the opening of calcium channels. J. Neurochem. 1988, 50, 1227-1232. [CrossRef] [PubMed]

24. Leech, C.A.; Habener, J.F. Insulinotropic glucagon-like peptide-1-mediated activation of non-selective cation currents in insulinoma cells is mimicked by maitotoxin. J. Biol. Chem. 1997, 272, 17987-17993. [CrossRef] [PubMed]

25. Soergel, D.G.; Gusovsky, F.; Yasumoto, T.; Daly, J.W. Stimulatory effects of maitotoxin on insulin release in insulinoma HIT cells: Role of calcium uptake and phosphoinositide breakdown. J. Pharmacol. Exp. Ther. 1990, 255, 1360-1365. [PubMed]

26. Choi, O.H.; Padgett, W.L.; Nishizawa, Y.; Gusovsky, F.; Yasumoto, T.; Daly, J.W. Maitotoxin: Effects on calcium channels, phosphoinositide breakdown, and arachidonate release in pheochromocytoma PC12 cells. Mol. Pharmacol. 1990, 37, 222-230. [PubMed]

27. Columbo, M.; Taglialatela, M.; Warner, J.A.; Macglashan, D.W.; Yasumoto, T.; Annunziato, L.; Marone, G. Maitotoxin, a novel activator of mediator release from human basophils, induces large increase in cytosolic calcium resulting in histamine, but not leukotriene-Crelease. J. Pharmacol. Exp. Ther. 1992, 263, 979-986. [PubMed]

28. Estacion, M.; Schilling, W.P. Maitotoxin-induced membrane blebbing and cell death in aortic endothelial cells. FASEB J. 2001, 1, 2.

29. Schilling, W.P.; Sinkins, W.G.; Estacion, M. Maitotoxin activates a nonselective cation channel and a P2Z/P2X(7)-like cytolytic pore in human skin fibroblasts. Am. J. Physiol. Cell Physiol. 1999, 277, C755-C765.

30. Schilling, W.P.; Wasylyna, T.; Dubyak, G.R.; Humphreys, B.D.; Sinkins, W.G. Maitotoxin and P2Z/P2X(7) purinergic receptor stimulation activate a common cytolytic pore. Am. J. Physiol. Cell Physiol. 1999, 277, C766-C776.

31. Sasaki, M.; Matsumori, N.; Maruyama, T.; Nonomura, T.; Murata, M.; Tachibana, K.; Yasumoto, T. The complete structure of maitotoxin, part I: Configuration of the $\mathrm{C}_{1}-\mathrm{C}_{14}$ side chain. Angew. Chem. Int. Ed. Engl. 1996, 35, 1672-1675. [CrossRef]

32. Nonomura, T.; Sasaki, M.; Matsumori, N.; Murata, M.; Tachibana, K.; Yasumoto, T. The complete structure of maitotoxin, part II: Configuration of the $\mathrm{C}_{135}-\mathrm{C}_{142}$ side chain and absolute configuration of the entire molecule. Angew. Chem. Int. Ed. Engl. 1996, 35, 1675-1678. [CrossRef]

33. Zheng, W.J.; DeMattei, J.A.; Wu, J.P.; Duan, J.J.W.; Cook, L.R.; Oinuma, H.; Kishi, Y. Complete relative stereochemistry of maitotoxin. J. Am. Chem. Soc. 1996, 118, 7946-7968. [CrossRef]

34. Gallimore, A.R.; Spencer, J.B. Stereochemical uniformity in marine polyether ladders-Implications for the biosynthesis and structure of maitotoxin. Angew. Chem. Int. Ed. Engl. 2006, 45, 4406-4413. [CrossRef] [PubMed]

35. Nicolaou, K.C.; Frederick, M.O. On the structure of maitotoxin. Angew. Chem. Int. Ed. 2007, 46, 5278-5282. [CrossRef] [PubMed] 
36. Nicolaou, K.C.; Cole, K.P.; Frederick, M.O.; Aversa, R.J.; Denton, R.M. Chemical synthesis of the GHIJK ring system and further experimental support for the originally assigned structure of maitotoxin. Angew. Chem. Int. Ed. 2007, 46, 8875-8879. [CrossRef] [PubMed]

37. Takahashi, M.; Ohizumi, Y.; Yasumoto, T. Maitotoxin, a $\mathrm{Ca}^{2+}$ channel activator candidate. J. Biolog. Chem. 1982, 257, 7287-7289.

38. Freedman, S.B.; Miller, R.J.; Miller, D.M.; Tindall, D.R. Interactions of maitotoxin with voltage-sensitive calcium channels in cultured neuronal cells. Proc. Natl. Acad. Sci. USA 1984, 81, 4582-4585. [CrossRef] [PubMed]

39. Cataldi, M.; Secondo, A.; D’Alessio, A.; Taglialatela, M.; Hofmann, F.; Klugbauer, N.; Di Renzo, G.; Annunziato, L. Studies on maitotoxin-induced intracellular $\mathrm{Ca}^{2+}$ elevation in Chinese hamster ovary cells stably transfected with cDNAs encoding for L-type $\mathrm{Ca}^{2+}$ channel subunits. J. Pharmacol. Exp. Ther. 1999, 290, 725-730. [PubMed]

40. Brereton, H.M.; Chen, J.L.; Rychkov, G.; Harland, M.L.; Barritt, G.J. Maitotoxin activates an endogenous non-selective cation channel and is an effective initiator of the activation of the heterologously expressed hTRPC-1 (transient receptor potential) non-selective cation channel in H4-IIE liver cells. Biochim. Biophys. Acta Mol. Cell Res. 2001, 1540, 107-126. [CrossRef]

41. Morales-Tlalpan, V.; Vaca, L. Modulation of the maitotoxin response by intracellular and extracellular cations. Toxicon 2002, 40, 493-500. [CrossRef]

42. Gutierrez, D.; Diaz de Leon, L.; Vaca, L. Characterization of the maitotoxin-induced calcium influx pathway from human skin fibroblasts. Cell Calcium 1997, 22, 31-38. [CrossRef]

43. Martinez-Francois, J.R.; Morales-Tlalpan, V.; Vaca, L. Characterization of the maitotoxin-activated cationic current from human skin fibroblasts. J. Physiol. Lond. 2002, 538, 79-86. [CrossRef] [PubMed]

44. Meunier, F.A.; Mattei, C.; Molgo, J. Marine toxins potently affecting neurotransmitter release. Prog. Mol. Subcell. Biol. 2009, 46, 159-186. [PubMed]

45. Frew, R.; Wang, Y.S.; Weiss, T.M.; Nelson, P.; Sawyer, T.W. Attenuation of maitotoxin-induced cytotoxicity in rat aortic smooth muscle cells by inhibitors of $\mathrm{Na}^{+} / \mathrm{Ca}^{2+}$ exchange, and calpain activation. Toxicon 2008, 51, 1400-1408. [CrossRef] [PubMed]

46. Wang, Y.S.; Weiss, M.T.; Yin, J.F.; Frew, R.; Tenn, C.; Nelson, P.P.; Vair, C.; Sawyer, T.W. Role of the sodium hydrogen exchanger in maitotoxin-induced cell death in cultured rat cortical neurons. Toxicon 2009, 54, 95-102. [CrossRef] [PubMed]

47. Martin, V.; Vale, C.; Antelo, A.; Hirama, M.; Yamashita, S.; Vieytes, M.R.; Botana, L.M. Differential effects of ciguatoxin and maitotoxin in primary cultures of cortical neurons. Chem. Res. Toxicol. 2014, 27, 1387-1400. [CrossRef] [PubMed]

48. Sinkins, W.G.; Estacion, M.; Prasad, V.; Goel, M.; Shull, G.E.; Kunze, D.L.; Schilling, W.P. Maitotoxin converts the plasmalemmal $\mathrm{Ca}^{2+}$ pump into a $\mathrm{Ca}^{2+}$-permeable nonselective cation channel. Am. J. Physiol. Cell Physiol. 2009, 297, C1533-C1543. [CrossRef] [PubMed]

49. De la Rosa, L.A.; Alvarez-Parrilla, E.; Martinez-Martinez, A. Biochemistry of maitotoxin. In Phycotoxins: Chemistry and Biochemistry; Botana, L.M., Ed.; Blackwell Publishing Ltd.: Oxford, UK, 2007; pp. 55-74.

50. Lundy, P.M.; Nelson, P.; Mi, L.; Frew, R.; Minaker, S.; Vair, C.; Sawyer, T.W. Pharmacological differentiation of the P2X(7) receptor and the maitotoxin-activated cationic channel. Eur. J. Pharmacol. 2004, 487, 17-28. [CrossRef] [PubMed]

51. Konoki, K.; Hashimoto, M.; Murata, M.; Tachibana, K. Maitotoxin-induced calcium influx in erythrocyte ghosts and rat glioma C6 cells, and blockade by gangliosides and other membrane lipids. Chem. Res. Toxicol. 1999, 12, 993-1001. [CrossRef] [PubMed]

52. Murata, M.; Gusovsky, F.; Sasaki, M.; Yokoyama, A.; Yasumoto, T.; Daly, J.W. Effect of maitotoxin analogs on calcium influx and phosphoinositide breakdown in cultured cells. Toxicon 1991, 29, 1085-1096. [CrossRef]

53. Holmes, M.J.; Lewis, R.J. Purification and characterisation of large and small maitotoxins from cultured Gambierdiscus toxicus. Nat. Toxins 1994, 2, 64-72. [CrossRef] [PubMed]

54. Murata, M.; Matsumori, N.; Konoki, K.; Oishi, T. Structural features of dinoflagellate toxins underlying biological activity as viewed by NMR. Bull. Chem. Soc. Jpn. 2008, 81, 307-319. [CrossRef]

55. Holmes, M.J.; Lewis, R.J.; Gillespie, N.C. Toxicity of Australian and French Polynesian strains of Gambierdiscus toxicus (Dinophyceae) grown in culture: Characterization of a new type of maitotoxin. Toxicon 1990, 28, 1159-1172. [CrossRef] 
56. Lewis, R.J.; Holmes, M.J.; Alewood, P.F.; Jones, A. Ionspray mass spectrometry of ciguatoxin-1, maitotoxin-2 and -3 , and related marine polyether toxins. Nat. Toxins 1994, 2, 56-63. [CrossRef] [PubMed]

57. Lewis, R.J.; Inserra, M.; Vetter, I.; Holland, W.C.; Hardison, D.R.; Tester, P.A.; Litaker, R.W. Rapid extraction and identification of maitotoxin and ciguatoxin-like toxins from Caribbean and Pacific Gambierdiscus using a new functional bioassay. PLoS ONE 2016, 11, e0160006. [CrossRef] [PubMed]

58. Litaker, R.W.; Vandersea, M.W.; Faust, M.A.; Kibler, S.R.; Chinain, M.; Holmes, M.J.; Holland, W.C.; Tester, P.A. Taxonomy of Gambierdiscus including four new species, Gambierdiscus caribaeus, Gambierdiscus carolinianus, Gambierdiscus carpenteri and Gambierdiscus ruetzleri (Gonyaulacales, Dinophyceae). Phycologia 2009, 48, 344-390. [CrossRef]

59. Smith, K.F.; Rhodes, L.; Verma, A.; Curley, B.G.; Harwood, D.T.; Kohli, G.S.; Solomona, D.; Rongo, T.; Munday, R.; Murray, S.A. A new Gambierdiscus species (Dinophyceae) from Rarotonga, Cook Islands: Gambierdiscus cheloniae sp. nov. Harmful Algae 2016, 60, 45-56. [CrossRef] [PubMed]

60. Fraga, S.; Rodríguez, F.; Riobó, P.; Bravo, I. Gambierdiscus balechii sp. nov. (Dinophyceae), a new benthic toxic dinoflagellate from the Celebes Sea (SW Pacific Ocean). Harmful Algae 2016, 58, 93-105. [CrossRef] [PubMed]

61. Fraga, S.; Rodríguez, F.; Caillaud, A.; Diogène, J.; Raho, N.; Zapata, M. Gambierdiscus excentricus sp. nov. (Dinophyceae), a benthic toxic dinoflagellate from the Canary Islands (NE Atlantic Ocean). Harmful Algae 2011, 11, 10-22. [CrossRef]

62. Fraga, S.; Rodríguez, F. Genus Gambierdiscus in the Canary Islands (NE Atlantic Ocean) with description of Gambierdiscus silvae sp. nov., a new potentially toxic epiphytic benthic dinoflagellate. Protist 2014, 165, 839-853. [CrossRef] [PubMed]

63. Nishimura, T.; Sato, S.; Tawong, W.; Sakanari, H.; Yamaguchi, H.; Adachi, M. Morphology of Gambierdiscus scabrosus sp. nov. (Gonyaulacales): A new epiphytic toxic dinoflagellate from coastal areas of Japan. J. Phycol. 2014, 50, 506-514. [CrossRef] [PubMed]

64. Kretzschmar, A.L.; Verma, A.; Harwood, D.T.; Hoppenrath, M.; Murray, S.A. Characterisation of Gambierdiscus lapillus sp. nov. (Gonyaulacales, Dinophyceae): A new toxic dinoflagellate from the Great Barrier Reef (Australia). J. Phycol. 2017, 53, 283-297. [CrossRef] [PubMed]

65. Gómez, F.; Qiu, D.J.; Lopes, R.M.; Lin, S.J. Fukuyoa paulensis gen. et sp. nov., a new genus for the globular species of the dinoflagellate Gambierdiscus (Dinophyceae). PLoS ONE 2015, 10, e0119676. [CrossRef] [PubMed]

66. Rhodes, L.; Smith, K.F.; Verma, A.; Curley, B.G.; Harwood, D.T.; Murray, S.; Kohli, G.S.; Solomona, D.; Rongo, T.; Munday, R.; et al. A new species of Gambierdiscus (Dinophyceae) from the south-west Pacific: Gambierdiscus honu sp. nov. Harmful Algae 2017, 65, 61-70. [CrossRef] [PubMed]

67. Tunin-Ley, A.; Chomérat, N.; Bilien, G.; Turquet, J. Taxonomic characterization of Gambierdiscus species in Reunion Island, Indian Ocean. In Proceedings of the GdR Phycotox \& GIS Cyano 2017, Gif-sur-Yvette, France, 14-16 March 2017.

68. Holland, W.C.; Litaker, R.W.; Tomas, C.R.; Kibler, S.R.; Place, A.R.; Davenport, E.D.; Tester, P.A. Differences in the toxicity of six Gambierdiscus (Dinophyceae) species measured using an in vitro human erythrocyte lysis assay. Toxicon 2013, 65, 15-33. [CrossRef] [PubMed]

69. Pisapia, F.; Holland, W.C.; Hardison, D.R.; Litaker, R.W.; Fraga, S.; Nishimura, T.; Adachi, M.; Nguyen-Ngoc, L.; Séchet, V.; Amzil, Z.; et al. Toxicity screening of 13 Gambierdiscus strains using neuro-2a and erythrocyte lysis bioassays. Harmful Algae 2017, 63, 173-183. [CrossRef] [PubMed]

70. Chinain, M.; Darius, H.T.; Ung, A.; Cruchet, P.; Wang, Z.; Ponton, D.; Laurent, D.; Pauillac, S. Growth and toxin production in the ciguatera-causing dinoflagellate Gambierdiscus polynesiensis (Dinophyceae) in culture. Toxicon 2010, 56, 739-750. [CrossRef] [PubMed]

71. Rhodes, L.; Harwood, T.; Smith, K.; Argyle, P.; Munday, R. Production of ciguatoxin and maitotoxin by strains of Gambierdiscus australes, G. pacificus and G. polynesiensis (Dinophyceae) isolated from Rarotonga, Cook Islands (vol 39, pg 185, 2014). Harmful Algae 2016, 55, 295. [CrossRef] [PubMed]

72. Kohli, G.S. Diversity and Genetics of Australasian Dinoflagellates, Including Gambierdiscus spp. the Causative Agent of Ciguatera Fish Poisoning; University of New South Wales: Sidney, Australia, 2013.

73. Rhodes, L.; Papiol, G.G.; Smith, K.; Harwood, T. Gambierdiscus cf. yasumotoi (Dinophyceae) isolated from New Zealand's sub-tropical northern coastal waters. N. Z. J. Mar. Freshw. Res. 2014, 48, 303-310. 
74. Rhodes, L.L.; Smith, K.F.; Verma, A.; Murray, S.; Harwood, D.T.; Trnski, T. The dinoflagellate genera Gambierdiscus and Ostreopsis from subtropical Raoul Island and North Meyer Island, Kermadec Islands. N. Z. J. Mar. Freshw. Res. 2017, 1-15. [CrossRef]

75. Litaker, R.W.; Holland, W.C.; Hardison, D.R.; Pisapia, F.; Hess, P.; Tester, P. Ciguatoxicity of Gambierdiscus and Fukuyoa species from the Caribbean and Gulf of Mexico. PLoS ONE 2017, unpublished.

76. Boada, L.D.; Zumbado, M.; Luzardo, O.P.; Almeida-González, M.; Plakas, S.M.; Granade, H.R.; Abraham, A.; Jester, E.L.; Dickey, R.W. Ciguatera fish poisoning on the West Africa Coast: An emerging risk in the Canary Islands (Spain). Toxicon 2010, 56, 1516-1519. [CrossRef] [PubMed]

77. Pérez-Arellano, J.L.; Luzardo, O.P.; Perez Brito, A.; Hernandez Cabrera, M.; Zumbado, M.; Carranza, C.; Angel-Moreno, A.; Dickey, R.W.; Boada, L.D. Ciguatera fish poisoning, Canary Islands. Emerg. Infect. Dis. 2005, 11, 1981-1982. [CrossRef] [PubMed]

78. Nascimento, S.M.; Diniz, B.; de Alencar, A.G.; Menegueli, A.C.; Menezes, M. First record of the ciguatera causing genus Gambierdiscus in Brazil. Harmful Algal News 2012, 45, 8-9.

79. Nascimento, S.M.; Melo, G.; Salgueiro, F.; Diniz, B.D.; Fraga, S. Morphology of Gambierdiscus excentricus (Dinophyceae) with emphasis on sulcal plates. Phycologia 2015, 54, 628-639. [CrossRef]

80. Caillaud, A.; de la Iglesia, P.; Barber, E.; Eixarch, H.; Mohammad-Noor, N.; Yasumoto, T.; Diogène, J. Monitoring of dissolved ciguatoxin and maitotoxin using solid-phase adsorption toxin tracking devices: Application to Gambierdiscus pacificus in culture. Harmful Algae 2011, 10, 433-446. [CrossRef]

81. Kibler, S.R.; Litaker, R.W.; Holland, W.C.; Vandersea, M.W.; Tester, P.A. Growth of eight Gambierdiscus (Dinophyceae) species: Effects of temperature, salinity and irradiance. Harmful Algae 2012, 19, 1-14. [CrossRef]

82. Xu, Y.; Richlen, M.L.; Liefer, J.D.; Robertson, A.; Kulis, D.; Smith, T.B.; Parsons, M.L.; Anderson, D.M. Influence of environmental variables on Gambierdiscus spp. (Dinophyceae) growth and distribution. PLoS ONE 2016, 11, e0153197. [CrossRef] [PubMed]

83. Roeder, K.; Erler, K.; Kibler, S.; Tester, P.; Van The, H.; Nguyen-Ngoc, L.; Gerdts, G.; Luckas, B. Characteristic profiles of ciguatera toxins in different strains of Gambierdiscus spp. Toxicon 2010, 56, 731-738. [CrossRef] [PubMed]

84. Rodríguez, I.; Genta-Jouve, G.; Alfonso, C.; Calabro, K.; Alonso, E.; Sánchez, J.A.; Alfonso, A.; Thomas, O.P.; Botana, L.M. Gambierone, a ladder-shaped polyether from the dinoflagellate Gambierdiscus belizeanus. Org. Lett. 2015, 17, 2392-2395. [CrossRef] [PubMed]

85. Watanabe, R.; Uchida, H.; Suzuki, T.; Matsushima, R.; Nagae, M.; Toyohara, Y.; Satake, M.; Oshima, Y.; Inoue, A.; Yasumoto, T. Gambieroxide, a novel epoxy polyether compound from the dinoflagellate Gambierdiscus toxicus GTP2 strain. Tetrahedron 2013, 69, 10299-10303. [CrossRef]

86. Babinchak, J.A.; Jollow, D.J.; Voegtline, M.S.; Higerd, T.B. Toxin production by Gambierdiscus toxicus isolated from the Florida Keys. Mar. Fish. Rev. 1986, 48, 53-56.

87. Nishimura, T.; Sato, S.; Tawong, W.; Sakanari, H.; Uehara, K.; Shah, M.M.; Suda, S.; Yasumoto, T.; Taira, Y.; Yamaguchi, H.; et al. Genetic diversity and distribution of the ciguatera-causing dinoflagellate Gambierdiscus spp. (Dinophyceae) in coastal areas of Japan. PLoS ONE 2013, 8, e60882. [CrossRef] [PubMed]

88. Bravo, I.; Figueroa, R.I.; Fraga, S. Cellular and nuclear morphological variability within a single species of the toxigenic dinoflagellate genus Gambierdiscus: Relationship to life-cycle processes. Harmful Algae 2014, 40, 1-8. [CrossRef]

89. Litaker, R.W.; Vandersea, M.W.; Faust, M.A.; Kibler, S.R.; Nau, A.W.; Holland, W.C.; Chinain, M.; Holmes, M.J.; Tester, P.A. Global distribution of ciguatera causing dinoflagellates in the genus Gambierdiscus. Toxicon 2010, 56, 711-730. [CrossRef] [PubMed]

90. The, H.V.; Lam, N.N.; Larsen, J. On a toxic benthic dinoflagellate Gambierdiscus toxicus isolated from Cau Island, South Central Viet Nam. In Proceedings of the 13th International Conference on Harmful Algae, Hong Kong, China, 3-7 November 2008.

91. Satake, M.; Murata, M.; Yasumoto, T. The structure of CTX3C, a ciguatoxin congener isolated from cultured Gambierdiscus toxicus. Tetrahedron Lett. 1993, 34, 1975-1978. [CrossRef]

92. Caillaud, A.; Yasumoto, T.; Diogène, J. Detection and quantification of maitotoxin-like compounds using a neuroblastoma (Neuro-2a) cell based assay. Application to the screening of maitotoxin-like compounds in Gambierdiscus spp. Toxicon 2010, 56, 36-44. [CrossRef] [PubMed] 
93. Hardison, D.R.; Holland, W.C.; McCall, J.R.; Bourdelais, A.J.; Baden, D.G.; Darius, H.T.; Chinain, M.; Tester, P.A.; Shea, D.; Quintana, H.A.; et al. Fluorescent receptor binding assay for detecting ciguatoxins in fish. PLoS ONE 2016, 11, e0153348. [CrossRef] [PubMed]

94. Mosmann, T. Rapid colorimetric assay for cellular growth and survival: Application to proliferation and cytotoxicity assays. J. Immunol. Methods 1983, 65, 55-63. [CrossRef]

95. O’Brien, P.J.; Irwin, W.; Diaz, D.; Howard-Cofield, E.; Krejsa, C.M.; Slaughter, M.R.; Gao, B.; Kaludercic, N.; Angeline, A.; Bernardi, P.; et al. High concordance of drug-induced human hepatotoxicity with in vitro cytotoxicity measured in a novel cell-based model using high content screening. Arch. Toxicol. 2006, 80, 580-604. [CrossRef] [PubMed]

96. Singh, S.; Carpenter, A.E.; Genovesio, A. Increasing the content of High-Content Screening. J. Biomol. Screen. 2014, 19, 640-650. [CrossRef] [PubMed]

97. Sérandour, A.L.; Ledreux, A.; Morin, B.; Derick, S.; Augier, E.; Lanceleur, R.; Hamlaoui, S.; Moukha, S.; Furger, C.; Biré, R.; et al. Collaborative study for the detection of toxic compounds in shellfish extracts using cell-based assays. Part I: Screening strategy and pre-validation study with lipophilic marine toxins. Anal. Bioanal. Chem. 2012, 403, 1983-1993. [CrossRef] [PubMed]

98. Vial, J.; Jardy, A. Experimental comparison of the different approaches to estimate LOD and LOQ of an HPLC method. Anal. Chem. 1999, 71, 2672-2677. [CrossRef]

99. Sanagi, M.M.; Ling, S.L.; Nasir, Z.; Hermawan, D.; Ibrahim, W.A.; Abu Naim, A. Comparison of signal-to-noise, blank determination, and linear regression methods for the estimation of detection and quantification limits for volatile organic compounds by gas chromatography. J. AOAC Int. 2009, 92, 1833-1838. [PubMed]

(C) 2017 by the authors. Licensee MDPI, Basel, Switzerland. This article is an open access article distributed under the terms and conditions of the Creative Commons Attribution (CC BY) license (http:/ / creativecommons.org/licenses/by/4.0/). 